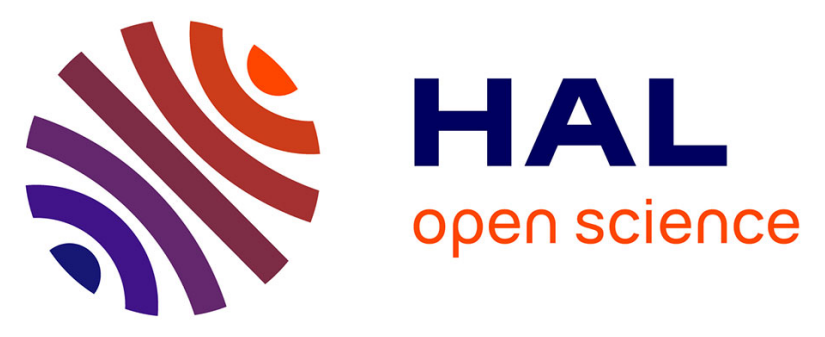

\title{
Synthesis of branched-phosphodiester and mannosecentered fucosylated glycoclusters and their binding studies with Burkholderia ambifaria lectin (BambL)
}

Caroline Ligeour, Aymeric Audfray, Emilie Gillon, Albert Meyer, Nicolas Galanos, Sébastien Vidal, Jean-Jacques Vasseur, Anne Imberty, François Morvan

\section{- To cite this version:}

Caroline Ligeour, Aymeric Audfray, Emilie Gillon, Albert Meyer, Nicolas Galanos, et al.. Synthesis of branched-phosphodiester and mannosecentered fucosylated glycoclusters and their binding studies with Burkholderia ambifaria lectin (BambL). RSC Advances, 2013, 3, pp.19515-19524. 10.1039/c3ra43807d . hal-00874578

\author{
HAL Id: hal-00874578 \\ https://hal.science/hal-00874578
}

Submitted on 18 Oct 2013

HAL is a multi-disciplinary open access archive for the deposit and dissemination of scientific research documents, whether they are published or not. The documents may come from teaching and research institutions in France or abroad, or from public or private research centers.
L'archive ouverte pluridisciplinaire HAL, est destinée au dépôt et à la diffusion de documents scientifiques de niveau recherche, publiés ou non, émanant des établissements d'enseignement et de recherche français ou étrangers, des laboratoires publics ou privés. 


\title{
Synthesis of branched-phosphodiester and mannose- centered fucosylated glycoclusters and their binding studies with Burkholderia ambifaria lectin (BambL) $\dagger$
}

\author{
Caroline Ligeour, ${ }^{\text {a }}$ Aymeric Audfray, ${ }^{b}$ Emilie Gillon, ${ }^{\mathrm{b}}$ Albert Meyer, ${ }^{\mathrm{a}}$ Nicolas Galanos, \\ Sébastien Vidal, ${ }^{c}$ Jean-Jacques Vasseur, ${ }^{a}$ Anne Imberty*b and François Morvan*a
}

Five fucosylated glycoclusters exhibiting 4, 6 or 8 residues were synthesised with two different spatial environments based on mannose-centered and branched-phosphodiester scaffolds. Their synthesis was performed in solution using phosphoramidite chemistry to generate phosphodiester linkages, combined with $\mathrm{Cu}(\mathrm{I})$-catalyzed azide-alkyne cycloaddition (CuAAC). The multivalent ligands were evaluated for their ability to bind to Burkholderia ambifaria Lectin (BambL). Binding evaluation was performed through inhibition of hemagglutination (HIA), surface plasmon resonance (SPR) and isothermal titration

Received 4th June 2013,

Accepted 12th August 2013

DOI: $10.1039 /$ c3ra43807d

www.rsc.org/advances microcalorimetry (ITC). All fucosylated glycoclusters exhibited a higher affinity to BambL than methyl $\alpha$ L-fucoside. A dissociation constant of $43 \mathrm{nM}$ was observed for the fucocluster exhibiting four residues with the branched-phosphodiester spatial environment corresponding to a 22-fold increase in comparison with methyl $\alpha$-L-fucoside. These multivalent fucoclusters represent the first example of ligands of high affinity to Bambl.

\section{Introduction}

Multivalent recognitions between lectins and carbohydrate ligands occur in biological processes such as cell-cell communication, inflammation, cancer metastasis and infection by pathogens (viruses or bacteria). ${ }^{1-3}$ Several synthetic multivalent glycoconjugates have been reported ${ }^{4-6}$ in order to compete with natural carbohydrate ligands on cell surface and to control or modulate these interactions leading to potential therapeutic applications. These resulting neoglycans are expected to display a much higher binding for the target than the sum of the constitutive interactions thanks to the so-called "cluster glycoside effect". 7,8 The concept of multivalency has emerged as a promising strategy to design efficient lectin inhibitors to avoid pathogen infections through anti-adhesive approaches. ${ }^{9-11}$ However, the design of good candidates is still empirical since the precise mode of recognition of multivalent glycoclusters is not fully understood. Several examples of

${ }^{a}$ Institut des Biomolécules Max Mousseron, UMR 5247, CNRS, Université Montpellier 1, Université Montpellier 2, Université Montpellier 2, CC1704, Place E. Bataillon, 34095, Montpellier Cedex 5, France. E-mail: morvan@univ-montp2.fr; Fax: (+33)467-042-029

${ }^{b} C E R M A V-C N R S$, affiliated with Université Joseph Fourier and ICMG, BP53 38041, Grenoble, France. E-mail: anne.imberty@cermav.cnrs.fr; Fax: (+33)476-547-203 ${ }^{c}$ Institut de Chimie et Biochimie Moléculaires et Supramoléculaires, Laboratoire de Chimie Organique 2-Glycochimie, UMR 5246, CNRS, Université Claude Bernard Lyon 1, 43 Boulevard du 11 Novembre 1918, F-69622, Villeurbanne, France $\dagger$ Electronic supplementary information (ESI) available: SPR and ITC data, ${ }^{1} \mathrm{H}$ and ${ }^{13}$ C NMR spectra for all new compounds. See DOI: $10.1039 /$ c3ra $43807 \mathrm{~d}$ glycoclusters built from different scaffolds have been reported targeting different plants, bacteria, viruses or human lectins. ${ }^{12-18}$ This strategy led to potent inhibitors of the HIV virus infection in cellular models. ${ }^{19}$ Similarly, modification at the aglycone of mannosides revealed a family of potent inhibitors of Escherichia coli bacterial infection based on their interactions with the FimH adhesin. ${ }^{20-23}$ Galactoclusters could also be used as inhibitors of $\beta$-galactosidase. ${ }^{24}$

Burkholderia ambifaria is an opportunistic pathogen that has originally been isolated from the environment and from sputum of cystic fibrosis patients. ${ }^{25}$ B. ambifaria is a major component of the rhizosphere of many crop plants including maize $^{26}$ and has interesting biocontrol properties due to pesticide activity. ${ }^{27}$ However, B. ambifaria belongs to the Burkholderia cepacia complex (Bcc), a group of genetically distinct but phenotypically similar Gram-negative bacteria that cause infection in patients who are immuno-compromised or suffering from granulomatous disease or cystic fibrosis (CF). ${ }^{28}$ In this latter case, it is responsible for the "cepacia syndrome" that leads to rapid lung deterioration and death in most cases. $^{29,30}$ Most of the Bcc organisms are highly resistant to all major classes of antibiotics. ${ }^{31}$ Opportunistic bacteria often use lectins, i.e. protein receptors with high specificity for glycoconjugates, to recognize and adhere to human tissues. ${ }^{10,32,33}$ More particularly, fucosylated glycoconjugates are present in higher quantities in CF lungs ${ }^{34}$ and appear to be a target for lectins from pathogenic bacteria such as Pseudomonas aeruginosa $^{35}$ and Burkholderia cenocepacia. ${ }^{36,37}$ 

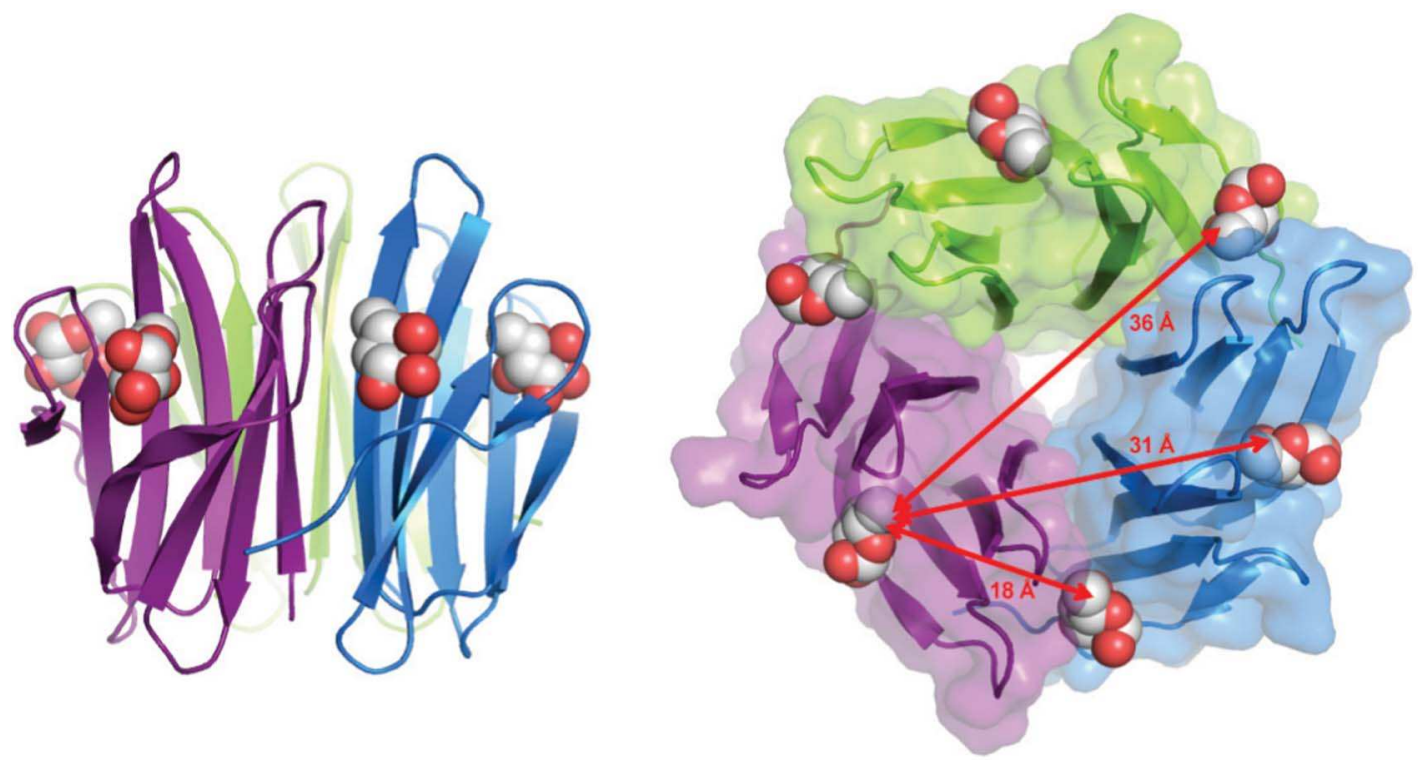

Fig. 1 Two orthogonal views of BambL trimer complexed with fucose, adapted from the crystal structure of BambL/blood group B complex (PDB code $3 Z W E$ ). ${ }^{38}$ The three BambL peptide chains are represented by ribbons of different colors (with the accessible surface on right panel) and the six fucose residues are represented by spheres.

Analysis of the available genomes of $B$. ambifaria allowed to identify a new fucose-binding lectin, BambL, ${ }^{38}$ with no similarity to lectins from $P$. aeruginosa and B. cenocepacia but rather related to lectins from the fungus Aleuria aurantia ${ }^{39}$ and from the phytopathogenic bacterium Ralstonia solanacearum. ${ }^{40}$ BambL shows a six bladed $\beta$-propeller architecture resulting from the association of 3 monomers with two binding sites per monomer. The overall lectin consequently exhibits 6 binding sites, all located on the same side of the protein (Fig. 1). BambL displays a micromolar affinity for fucose and binds strongly to cell or cell-like surfaces such as human tissues or mucins. Because of the characteristics (multivalency, topology, affinity...) of this B. ambifaria lectin, the design of synthetic, multivalent, high affinity ligands can be of great interest. Such BambL ligands can be used for the development of antiadhesive compounds against $B$. ambifaria infections and also for a better understanding of multivalent interactions.

This study reports the design and synthesis of five multivalent fucosylated ligands prepared from a mannose-based core or a branched-phosphodiester scaffold and bearing four, six or eight epitopes. Their binding properties towards BambL were evaluated using hemagglutination inhibitory assay (HIA), surface plasmon resonance (SPR) and isothermal titration microcalorimetry (ITC).

\section{Results and discussion}

\section{Synthesis}

Two families of fucosylated glycoclusters were prepared starting from two different scaffolds. The first family ( 1 to $\mathbf{3}$ ) was synthesised using a mannose-core on which four or eight fucose residues were introduced. Two mannose-centered tetrafucosylated clusters were elaborated using different linker lengths between the mannose core and the fucose moiety such as a phosphopropyltriazolyltriethylene glycol (POProTzEG 3 , 15atoms length) and a phosphodiethyleneglycolmethylene-triazolyltriethylene glycol ( $\mathrm{POEG}_{2} \mathrm{MTzEG}_{3}, 20$-atoms length) in order to evaluate the influence of the linker length on the binding properties. A mannose-centered octafucosylated glycocluster was prepared with POProTzEG 3 linkers and was used to evaluate the influence of valency on the binding efficiency. The second family displays a branched-phosphodiester spatial arrangement with four or six fucose residues. They were prepared on a pentaerythritol/1,1,1-(tris-hydroxymethyl)ethane core with a methylenetriazolyltriethylene glycol $\left(\mathrm{MTzEG}_{3}, 12-\right.$ atoms length) linker (Fig. 2). The five fucoclusters, exhibiting 4,6 or 8 residues, were synthesized at hundred-milligram scale using a combination of phosphoramidite chemistry ${ }^{41}$ and $\mathrm{Cu}(\mathrm{I})$-catalyzed azide-alkyne cycloaddition (CuAAC) or "click" chemistry. ${ }^{42,43}$ The resulting fucosylated glycoclusters, except 3, exhibit negatively charged phosphodiester linkages that lead to glycoclusters highly soluble in water and could also bring additional interaction with the lectin.

We developed such a strategy for the synthesis of glycoclusters 1-5 because the coupling between a hydroxyl and a phosphoramidite derivative activated with benzylthioltetrazole is very efficient with quantitative conversion. Thus, the reaction of phosphoramitides $\mathbf{8 a}-\mathbf{c}$ on the four hydroxyls of the mannose core is much more efficient than four alkylations as performed by Dubber and Lindhorst. $^{44}$ This strategy allowed also the straightforward synthesis of mannosecentered octa-pentynyl using the bis-alkynyl-linker phosphoramidite derivative 8c. Furthermore, the introduction of the alkynyl-linkers proceeded by an one pot procedure and the work-up was just an aqueous extraction affording the pure 

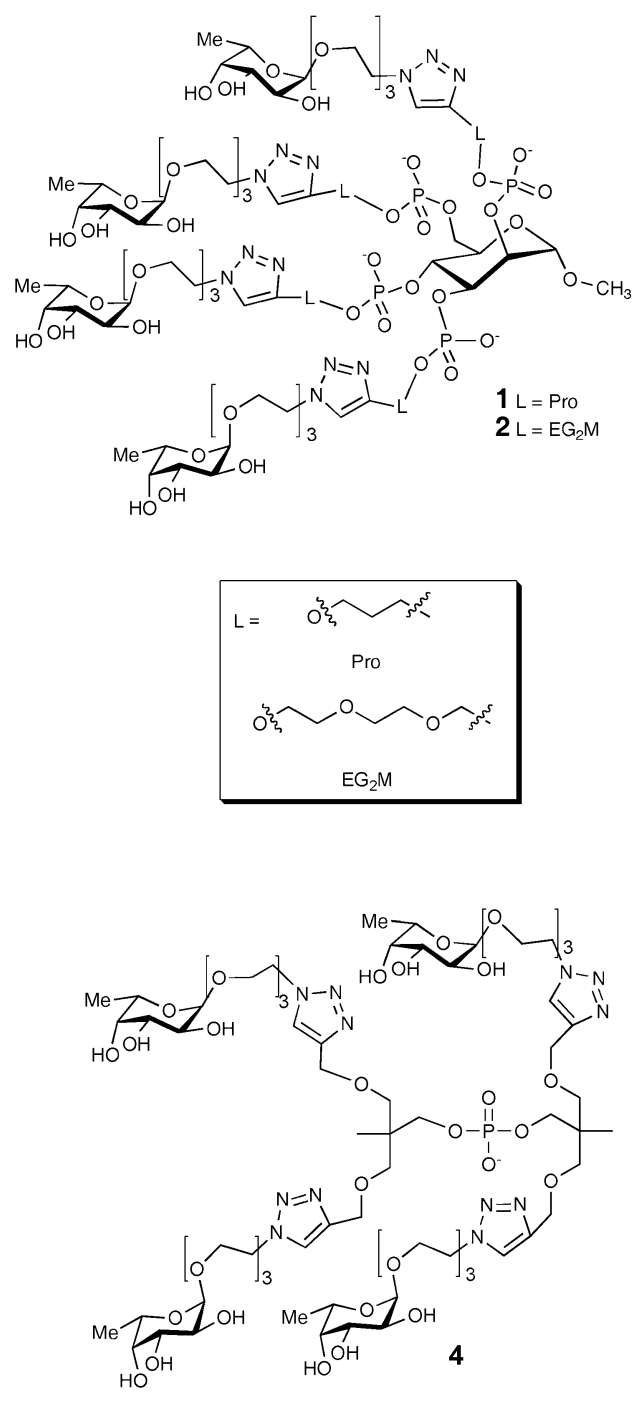
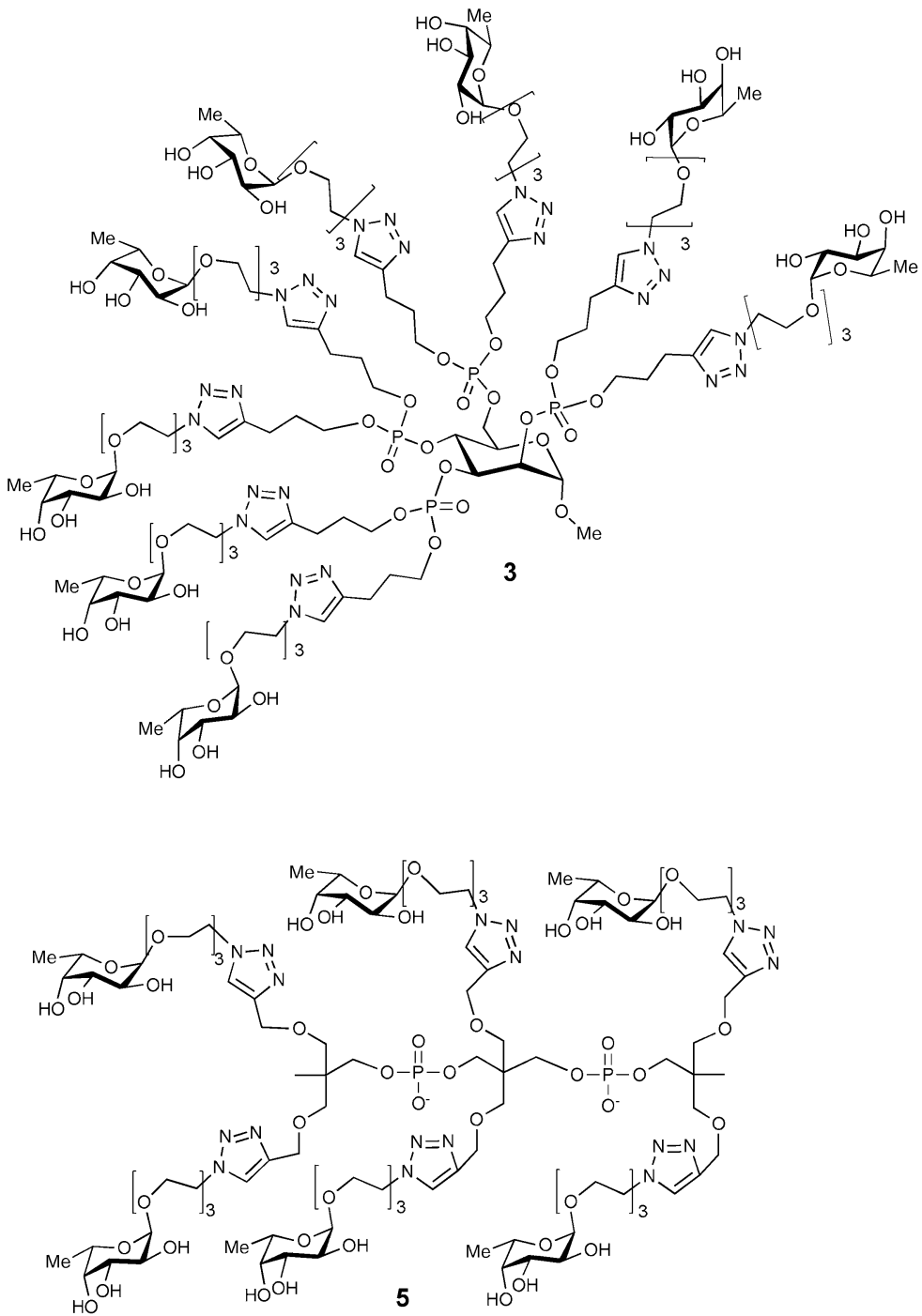

Fig. $\mathbf{2}$ Structure of fucoclusters $\mathbf{1}$ to $\mathbf{5}$.

corresponding poly-alkynylated scaffolds 9a-c with high yields (81-98\%). Eventually, fucose azide derivatives were conjugated by $\mathrm{CuAAC}$.

The glycomimetics 1-3 were synthesized in three steps starting from mannose $\mathbf{6}$ (Scheme 1). Firstly, mannose was glycosylated by methanol under acidic catalysis using Dowex $50 \mathrm{~W}$-X8 resin $\mathrm{H}^{+}$form affording methyl $\alpha$-D-mannopyranoside 7. ${ }^{45}$ Then, each hydroxyl was phosphorylated using the alkynylated phosphoramidites $\mathbf{8 a},{ }^{46} \mathbf{8 b}^{47}$ or $\mathbf{8 c}^{48}$ leading to phosphitetriester linkages. The small excess of phosphoramidite was hydrolysed by addition of water and phosphitetriester linkages were then oxidized by means of solid-supported metaperiodate ${ }^{49}$ affording the mannose-based platform exhibiting four or eight pent-4-ynyl residues 9a or 9c but also four propargyl diethyleneglycyl groups $\mathbf{9 b}$. During the process, the excess of phosphoramidite (8a-c) was hydrolysed affording a $H$-phosphonate diester that was oxidized leading to its negatively charged phosphodiester derivative. This water soluble side-product was easily removed by aqueous extrac- tion. Finally, platforms 9a-c were conjugated with the azidotriethyleneglycol functionalized fucoside $\mathbf{1 0}^{50}$ by CuAAC using copper nanopowder affording the hydroxylated fucoclusters 1-3 after ammonia treatment and purification by $\mathrm{C}_{18}$ reverse phase chromatography.

The branched-phosphodiester-shaped fucoclusters $\mathbf{4}$ and $\mathbf{5}$ were synthesized, in two steps, using bis-propargyloxymethyl2,2-propanol phosphoramidite $\mathbf{1 3}^{48}$ which was coupled once to bis-propargyloxymethyl-2,2-propanol $\mathbf{1 1}^{48}$ or twice to bispropargyloxymethyl-2,2-propane-1,3-diol $\mathbf{1 2}^{51}$ using tetrazole as activator (Scheme 2). After addition of water to hydrolyse the excess of 13, solid-supported meta-periodate was added to oxidize the phosphitetriester linkages into phosphate triesters affording the tetra-alkynylated $\mathbf{1 4}$ and hexa-alkynylated $\mathbf{1 5}$ platforms respectively. Each of them was conjugated with azidotriethyleneglycol functionalized fucoside $\mathbf{1 0}$ by CuAAC using copper nanopowder affording fucoclusters $\mathbf{4}$ and $\mathbf{5}$ respectively, after ammonia treatment and purification by $\mathrm{C}_{18}$ reverse phase chromatography 


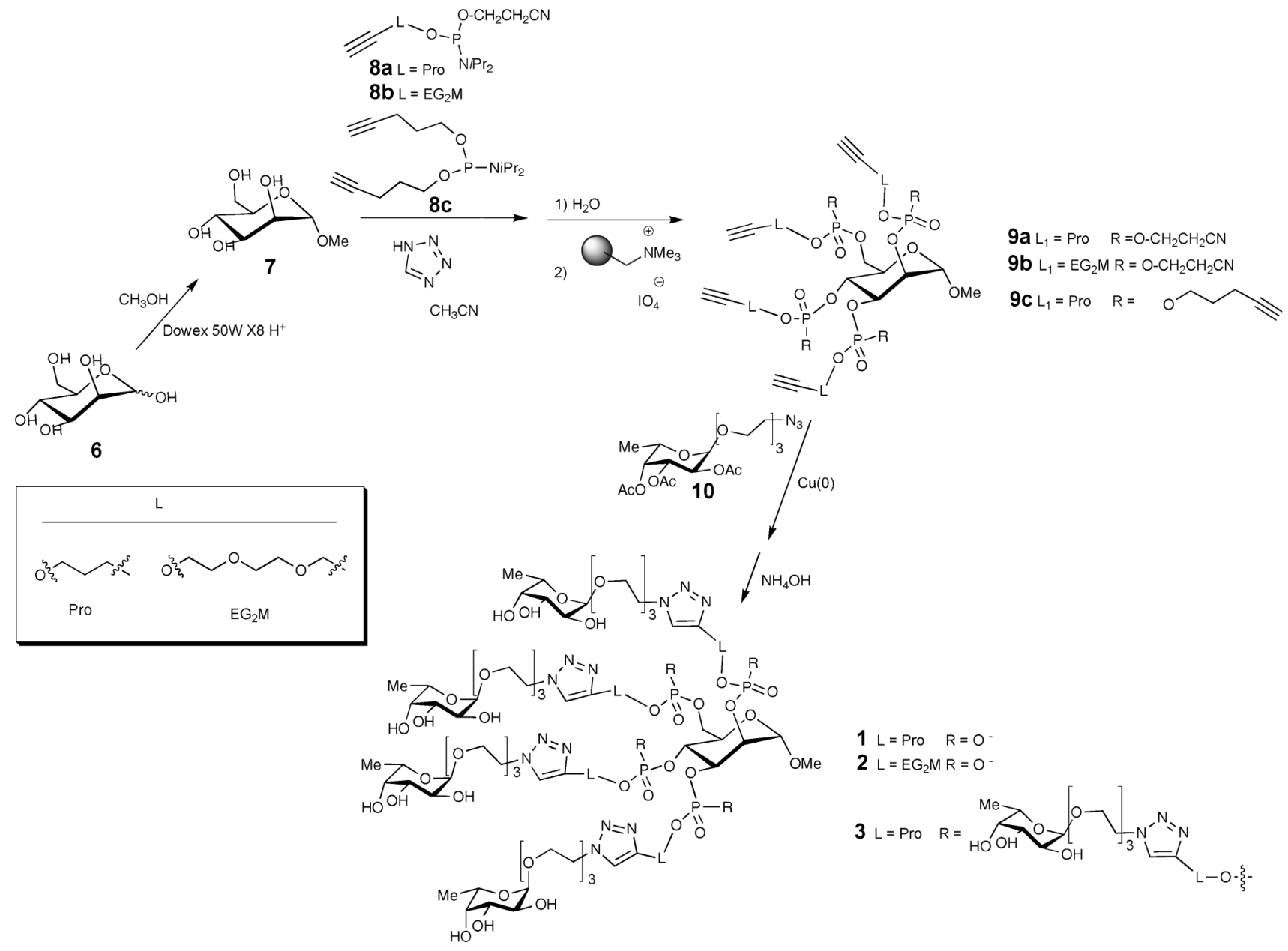

Scheme 1 Synthesis of mannose-centered tetra- and octa-fucoclusters 1 Man (ProTzEG 3 -Fuc) 2 Man(EG $\left.\mathrm{MTzEG}_{3}-\mathrm{Fuc}\right)_{4}$ and $3 \mathrm{Man}\left[\left(\operatorname{ProTzEG}{ }_{3}-\mathrm{Fuc}\right)_{2}\right]_{4}$. Pro $=$ propyl, $\mathrm{EG}_{2} \mathrm{M}$ = diethyleneglycol methylene, Gray ball represents polystyrene solid support.

\section{Interaction of the fucoclusters with BambL}

The binding of BambL to the fucosylated glycoclusters was evaluated according to different assays. BambL is able to agglutinate red cells by crosslinking glycoconjugates on their surface, and therefore multivalent glycoclusters can inhibit this hemagglutination. The potency of the competition is defined by the minimum inhibitory concentration (MIC)
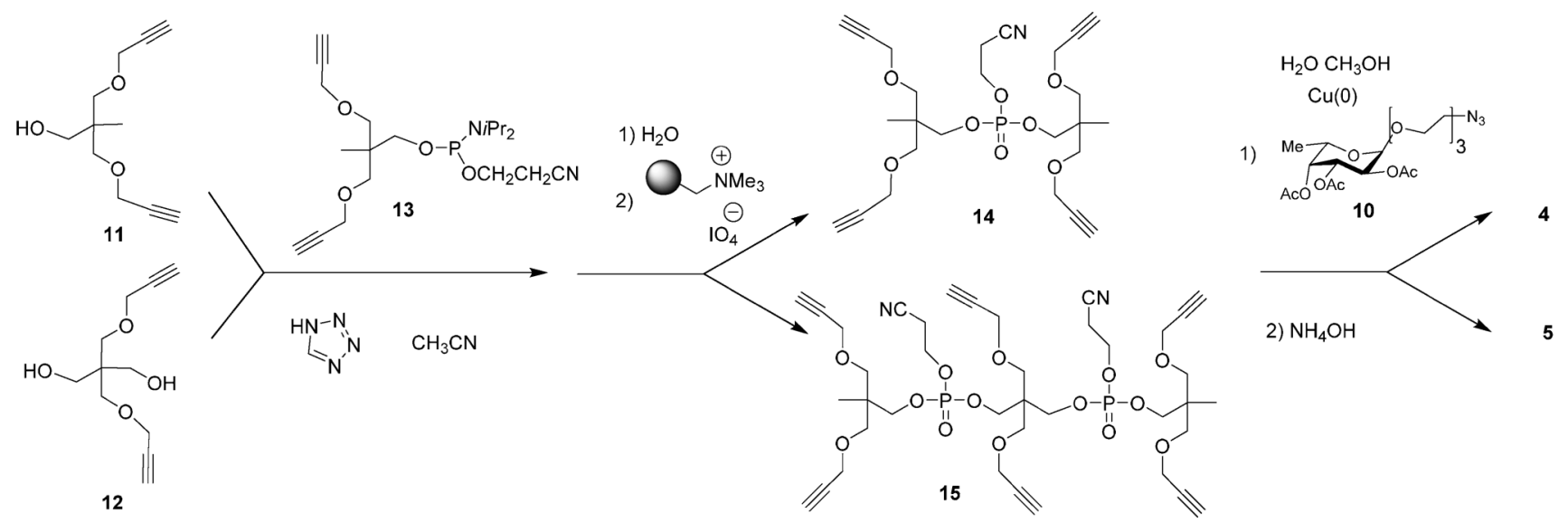

Scheme 2 Synthesis of branched-phosphodiester fucoclusters $4 \mathrm{BPO}\left(\mathrm{MTzEG}_{3}-\mathrm{Fuc}\right)_{4}, \mathbf{5} \mathrm{BPO}\left(\mathrm{MTzEG}_{3}-\mathrm{Fuc}_{6}\right.$. 
Table 1 HIA and SPR evaluation for binding of $\alpha$ MeFuc and multivalent glycoclusters to BambL

\begin{tabular}{lllrlr}
\hline Ligand & Valence & $\begin{array}{l}\text { HIA } \\
\text { MIC }(\mu \mathrm{M})\end{array}$ & $\beta^{a}$ & \multicolumn{1}{l}{ SPR } \\
IC $_{50}(\mu \mathrm{M})$ & $\beta^{a}$ \\
\hline$\alpha \mathrm{MeFu}$ & 1 & 62.5 & 1 & 16.3 & 1 \\
$\mathbf{1}$ & 4 & 3.9 & 16 & 0.191 & 85 \\
$\mathbf{2}$ & 4 & 3.9 & 16 & 0.154 & 106 \\
$\mathbf{3}$ & 8 & 0.24 & 256 & 0.169 & 96 \\
$\mathbf{4}$ & 4 & 0.24 & 256 & 0.462 & 35 \\
$\mathbf{5}$ & 6 & 0.37 & 171 & 0.170 & 96
\end{tabular}

${ }^{a} \beta$ corresponds to the ratio of the $\alpha \mathrm{MeFuc}$ value over the value of the considered fucocluster.

required for inhibiting the agglutination of erythrocytes. This method is based on visual analysis, and is therefore only semiquantitative, but it has the advantage to use the biological targets for the lectin action. The mannose-centered tetrafucosylated glycoclusters ( 1 and 2 ) displayed a similar binding profiles regardless of the linker length with potencies $(\beta) 16$ fold better than for the monovalent reference methyl $\alpha-\mathrm{L}^{-}$ fucopyranoside $\alpha$ MeFuc (Table 1). $\alpha$ MeFuc was chosen as control since its aglycon could be considered similar to the beginning of the triethyleneglycol moiety. The three other glycoclusters displayed a similar and stronger inhibition of hemagglutination with potencies between 171 and 256-fold.

SPR experiments were also conducted as inhibition assays, using increasing concentrations of glycoclusters to inhibit the binding of circulating BambL to $\alpha$-fucosides attached on the chip surface. Sensorgramms showed a very fast association of the lectin and a very slow dissociation due to multivalent interaction of BambL on the surface (Fig. 3A, ESI $\dagger$ ). Inhibition curves have been plotted based on the response level at the end of the equilibrium phase. Inhibition curves obtained with glycoclusters are different to those with $\alpha \mathrm{MeFuc}$, because of multivalent interactions of BambL resulting in partial aggregation and sharper sigmoid shape (Fig. 3B). The resulting $\mathrm{IC}_{50}$ values (Table 1) confirmed that all multivalent glycoclusters are more potent competitors than $\alpha$ MeFuc with rather similar
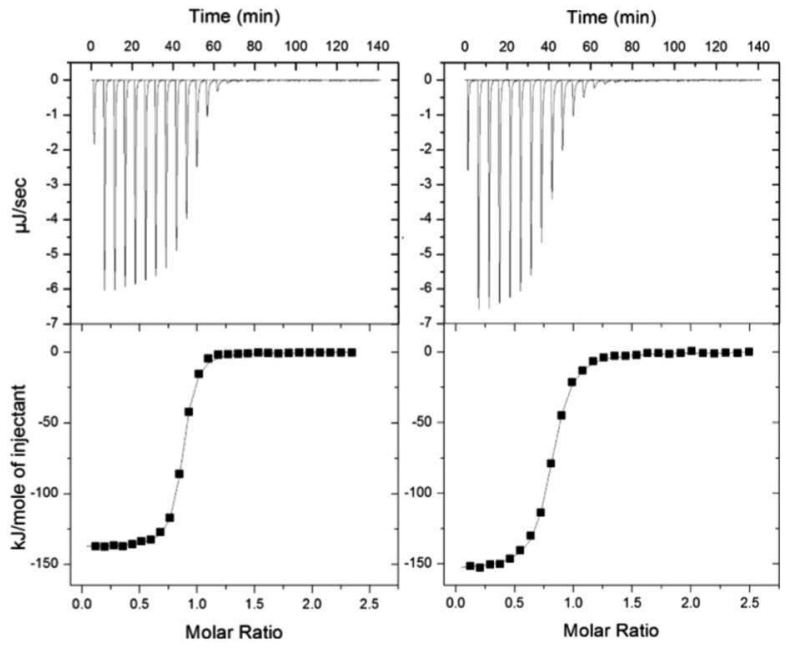

Fig. 4 Raw ITC data (top) obtained by injections of glycoclusters in a solution of BambL and the corresponding integrated titration curve (bottom). Left: $150 \mu \mathrm{M}$ 4 in $13.3 \mu \mathrm{M}$ BambL. Right: $150 \mu \mathrm{M} \mathbf{1}$ in $12.5 \mu \mathrm{M}$ Bamb.

improvement ratio $(\beta)$ between 35 and 106-fold. With this technique, the tetravalent compound $\mathbf{4}$ seems to be a slightly weaker inhibitor than the other compounds. This discrepancy in the binding profile of glycocluster 4 between HIA and SPR experiments could be attributed to the different experimental setup for each technique, and ITC data reported below will select this glycocluster $\mathbf{4}$ as the best ligand for BambL. Therefore, the surface-bound fucosides present on the sensorchip used in the SPR experiments provides a situation quite different from the "in solution" conditions found in HIA and ITC experiments where the interacting partners are all present in solution and none is bound to a surface.

Finally, the binding of BambL to fucoclusters 1-5 was studied by isothermal titration microcalorimetry (ITC) to determine the dissociation constant $\left(K_{\mathrm{D}}\right)$ and stoichiometry $(N)$ of interaction but also the thermodynamic parameters such as the enthalpy of binding $(\Delta H)$ (Fig. 4).
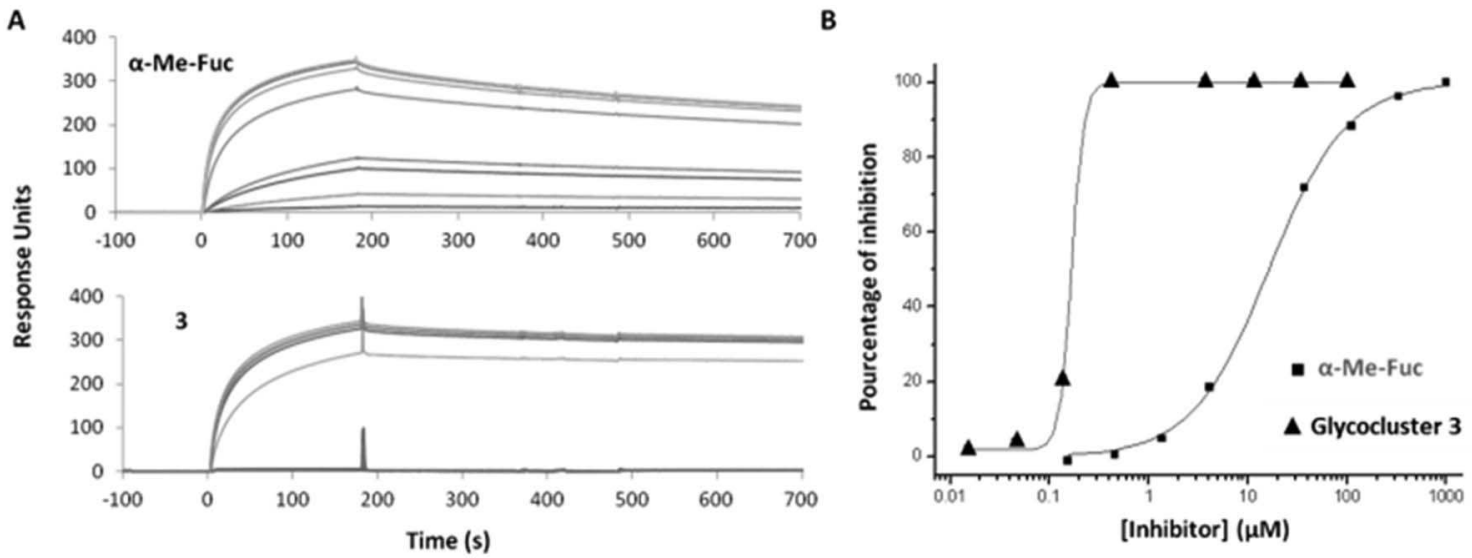

Fig. 3 Analysis of BambL/fucosylated glycoclusters interactions by inhibition assay using surface plasmon resonance. (A) Sensorgramms of BambL binding to an $\alpha$-fucosylated sensorchip with increasing concentrations of $\alpha$ MeFuc and $\mathbf{3}$ (from $0.005 \mu \mathrm{M}$ to $100 \mu \mathrm{M}$ ). (B) Inhibition curve of $\mathbf{3}$ compared to $\alpha \mathrm{Mefuc}$. 
Table 2 Titration microcalorimetry data for the interaction between BambL and fucoclusters 1-5. Standard deviations result from experimental data performed in duplicates or triplicates

\begin{tabular}{|c|c|c|c|c|c|c|c|c|}
\hline Ligand & Valence & $N^{a}$ & $\%$ Fuc bound & $K_{\mathrm{D}}(\mathrm{nM})$ & $-\Delta H\left(\mathrm{~kJ} \mathrm{~mol}^{-1}\right)$ & $-T \Delta S\left(\mathrm{~kJ} \mathrm{~mol}^{-1}\right)$ & $-\Delta G\left(\mathrm{~kJ} \mathrm{~mol}^{-1}\right)$ & $\beta^{b}$ \\
\hline$\alpha \mathrm{MeFuc}^{c}$ & 1 & 6.06 & 100 & $960 \pm 30$ & $47.8 \pm 1.8$ & 13.5 & 34.3 & 1 \\
\hline 1 & 4 & 2.34 & 64 & $111.2 \pm 0.1$ & $155 \pm 1$ & 116 & 40 & 9 \\
\hline 2 & 4 & 3.27 & 46 & $100 \pm 20$ & $101.7 \pm 0.6$ & 61 & 40 & 10 \\
\hline 3 & 8 & 1.47 & 51 & $57 \pm 3$ & $240 \pm 4$ & 199 & 41 & 17 \\
\hline 4 & 4 & 2.37 & 63 & $43 \pm 2$ & $146 \pm 8$ & 104 & 42 & 22 \\
\hline 5 & 6 & 1.26 & 79 & $93 \pm 5$ & $273 \pm 8$ & 233 & 40 & 10 \\
\hline
\end{tabular}

${ }^{a}$ Number of glycoclusters per BambL trimeric $\beta$-propeller. ${ }^{b}$ From Audfray et al. ${ }^{38 c} \beta$ corresponds to the ratio of the $\alpha$ MeFuc Kd value over the value of the considered fucocluster.

ITC measurements performed with the mannose-centered tetrafucosides 1 and 2 provided similar $K_{\mathrm{D}}$ values close to 100 $\mathrm{nM}$ that represent a 10 -fold improvement compared to reported data obtained with $\alpha \mathrm{MeFuc}^{38}$ (Table 2). The octavalent compound $\mathbf{3}$ is almost twice as good, as one could expect with the increase of valency. The highest affinity compound is the tetravalent branched-phosphodiester-based compound 4 with a $K_{\mathrm{D}}$ value of $43 \mathrm{nM}$, corresponding to a 22 -fold increase in comparison with $\alpha \mathrm{MeFuc}$. The increases of affinity for multivalent compounds are of the same range as the ones observed with SPR, although not always in the same order, again probably due to the different experimental setup. Concerning the lower affinity of the branched hexafucose $\mathbf{5}$, in respect with branched tetracluster $\mathbf{4}$, it has been reported several times that the global topology of a glycocluster is often more important than the number of carbohydrates to gain a high affinity. The possible explanation is that fucose residues are too close and lead to a steric hindrance.

Analysis of the stoichiometry of binding $(N)$ was performed by evaluating the ratio of glycocompounds bound per $\beta$-propeller. For the tetravalent compounds, this value varies approximately from 3 to 2 , corresponding to roughly the binding to the lectin of two to three fucose residues per tetravalent compounds $(46 \%$ to $64 \%$ of fucose residues bound). This value is in agreement with the enthalpy of binding varying from -150 to $-100 \mathrm{~kJ} \mathrm{~mol}^{-1}$. The compound 4 has higher affinity since $63 \%$ of the fucose residues are bound, resulting in a strong $\Delta H$, which is associated to relatively low entropy barrier $(\Delta S)$. The hexavalent 5 and octavalent 3 compounds have much stronger enthalpy of binding (with more fucose residues involved) but associated with higher entropy cost. These glycoclusters involved roughly 5 and 4 fucose residues respectively in the interaction with the lectin $(79 \%$ and $51 \%$ of fucose bound).

\section{Conclusion}

A series of five multivalent L-fucosylated glycoclusters exhibiting four, six or eight residues and with two different architectures were synthesized, in a few steps, using phosphoramidite chemistry and CuAAC "Click" chemistry. The affinities of the fucoclusters for BambL have been evaluated via HIA, SPR and ITC studies. These fucosylated glycoclusters are the first reported and studied for their binding properties towards the bacterial lectin BambL from B. ambifaria. They displayed a better affinity in comparison with the monovalent methyl $\alpha$-L-fucoside with an increase of potency from 9 to 22 . The lowest $K_{\mathrm{D}}$ value (43 nM) was found for a tetrameric cluster with a branched-phosphodiester scaffold illustrating that spatial arrangement is a very important parameter in the recognition event since hexa- of octa-valent glycoclusters did not display much better binding properties towards this lectin. Even though six binding sites are available for cross-linking with the fucoside epitopes of the glycoclusters, this chelate binding mode is most probably not observed in the present case since moderate potencies were observed. Nevertheless, the nanomolar affinity measured for these glycoclusters is highly compatible with applications in anti-adhesive therapy against bacterial infection.

\section{Experimental section}

Materials and methods: All reagents were commercial and used without further purification. Acetonitrile was distilled over $\mathrm{CaH}_{2}$. Phosphorylations were performed under an argon atmosphere. NMR spectra were recorded at $293 \mathrm{~K}$ using a 400 $\mathrm{MHz}$ or $600 \mathrm{MHz}$ spectrometer (Bruker). Shifts are referenced relative to deuterated solvent residual peaks. MALDI-TOF mass spectra were recorded on a Voyager mass spectrometer (Perspective Biosystems, Framingham, MA) equipped with a nitrogen laser. High-resolution (HR-ESI-QToF) mass spectra were recorded using a Q-Tof Micromass spectrometer. Thinlayer chromatography (TLC) was carried out on aluminum sheets coated with silica gel 60 F254 (Merck). TLC plates were inspected by UV light $(\lambda=254 \mathrm{~nm})$ and developed by treatment with a mixture of $10 \% \mathrm{H}_{2} \mathrm{SO}_{4}$ in $\mathrm{EtOH} / \mathrm{H}_{2} \mathrm{O}(1: 1 \mathrm{v} / \mathrm{v})$ followed by heating. Reverse phase chromatography was performed with $\mathrm{C}_{18}$ flash column.

\section{Synthesis}

General procedure for phosphorylation. A solution of methyl $\alpha$-D-mannopyranoside ${ }^{45} 7$ (50 mg, $\left.0.26 \mathrm{mmol}, 1 \mathrm{eq}\right)$ in anhydrous dimethylformamide-acetonitrile $(1: 1.5, \mathrm{v} / \mathrm{v})$ was stirred for $1.5 \mathrm{~h}$ with molecular sieves $(3 \AA)$. Then, the alkyne phosphoramidite 8a-c $(1.30 \mathrm{mmol}, 5 \mathrm{eq})$ and a solution of tetrazole (0.4 M in anhydrous $\mathrm{CH}_{3} \mathrm{CN}, 6.4 \mathrm{~mL}, 2.60 \mathrm{mmol}, 10$ eq) were added. The mixture was stirred at $30{ }^{\circ} \mathrm{C}$ for $2 \mathrm{~h}$ and 
the reaction was stopped by addition of water. $\mathrm{A}_{26}\left(\mathrm{IO}_{4}{ }^{-}\right)$resin $(1.0 \mathrm{~g}, 2.50 \mathrm{mmol}, 9.6 \mathrm{eq})$ was added and the mixture was stirred for $2 \mathrm{~h}$. After filtration of the resin and addition of dichloromethane $(40 \mathrm{~mL})$, the reaction was washed with an aqueous saturated solution of $\mathrm{NaHCO}_{3}(60 \mathrm{~mL})$ and brine (60 $\mathrm{mL})$. The organic layer was dried $\left(\mathrm{Na}_{2} \mathrm{SO}_{4}\right)$, filtered and concentrated to afford the desired tetra- or octa-alkynylated mannose derivatives 9a-c.

1-Methyl-2,3,4,6-tetra-O-pentynylphosphotriester- $\alpha$-D-mannopyranoseide 9a. Obtained as a pale yellow oil (208 $\mathrm{mg}, 81 \%)$. ${ }^{1} \mathrm{H}$ NMR $\left(300 \mathrm{MHz}, \mathrm{D}_{2} \mathrm{O}\right) \delta 4.98(\mathrm{~d}, J=2.10 \mathrm{~Hz}, 1 \mathrm{H}, \mathrm{H}-1), 4.87-$ 4.57 (m, 3H, H-2, H-5, H-6), 4.37-4.12 (m, 16H, $\mathrm{OCH}_{2} \mathrm{CH}_{2} \mathrm{CN}$, $\mathrm{POCH}_{2} \mathrm{CH}_{2}$ ), 3.94-3.89 (m, 1H, H-6), 3.45 (s, 4H, $\left.\mathrm{OCH}_{3}, \mathrm{H}-3\right)$, $3.40(\mathrm{~m}, 1 \mathrm{H}, \mathrm{H}-4), 2.88-2.78\left(\mathrm{~m}, 8 \mathrm{H}, \mathrm{CH}_{2} \mathrm{CN}\right), 2.39-2.34(\mathrm{~m}, 4 \mathrm{H}$, $\mathrm{CH}_{2} \mathrm{CH}_{2} \mathrm{CCH}$ ), 2.08-1.90 (m, 8H, $\mathrm{POCH}_{2} \mathrm{CH}_{2}$ ), 1.73-1.64 (m, $\left.4 \mathrm{H}, \mathrm{CH}_{2} \mathrm{CCH}\right) .{ }^{31} \mathrm{P}$ NMR $\left(162 \mathrm{MHz}, \mathrm{CDCl}_{3}\right) \delta-1.65--3.01(\mathrm{~m}$, 1P). ${ }^{13} \mathrm{C} \mathrm{NMR}\left(100 \mathrm{MHz}, \mathrm{CDCl}_{3}\right) \delta 115.5(\mathrm{CN}), 98.3(\mathrm{C}-1), 81.5$ $\left(\mathrm{OCH}_{2} \mathrm{CCH}\right), 68.5\left(\mathrm{CH}_{2} \mathrm{CCH}, \mathrm{C}-2, \mathrm{C}-5, \mathrm{C}-6\right), 65.6$ (C-3, C-4), 60.9 $\left(2 \mathrm{~s}, \mathrm{POCH}_{2}\right), 55.7\left(\mathrm{OCH}_{3}\right), 27.7\left(\mathrm{POCH}_{2} \mathrm{CH}_{2}\right), 18.7\left(\mathrm{CH}_{2} \mathrm{CN}\right)$, $13.1 \quad\left(\mathrm{CH}_{2} \mathrm{CH}_{2} \mathrm{CCH}\right)$. MS MALDI-TOF ${ }^{+} \mathrm{m} / \mathrm{z}$ calcd for $\mathrm{C}_{39} \mathrm{H}_{55} \mathrm{~N}_{4} \mathrm{O}_{18} \mathrm{P}_{4}[\mathrm{M}+\mathrm{H}]^{+}$: 991.76 found 991.86. HR-ESI-QToF MS (positive mode): $m / z$ calcd for $\mathrm{C}_{39} \mathrm{H}_{55} \mathrm{~N}_{4} \mathrm{O}_{18} \mathrm{P}_{4}[\mathrm{M}+\mathrm{H}]^{+}$ 991.2465 found 991.2462.

1-Methyl-2,3,4,6-tetra-O-propargyldiethyleneglycylphosphotriestero-D-mannopyranoseide 9b. Obtained as a colorless oil (279 mg, 87\%). ${ }^{1} \mathrm{H}$ NMR (400 MHz, $\mathrm{CDCl}_{3}$ ) $\delta 4.93$ (d, $\left.J=2.42 \mathrm{~Hz}, 1 \mathrm{H}, \mathrm{H}-1\right)$, 4.84-4.79 (m, 1H, H-6), 4.73-4.59 (m, 2H, H-2, H-5), 4.37-4.18 (m, 16H, $\mathrm{POCH}_{2} \mathrm{CH}_{2} \mathrm{CN}, \mathrm{POCH}_{2} \mathrm{CH}_{2}$ ), 4.17-4.12 (m, 8H, OCH $\mathrm{CCH}_{2}$ ), 3.86-3.80 (m, $1 \mathrm{H}, \mathrm{H}-6), 3.68\left(\mathrm{~m}, 8 \mathrm{H}, \mathrm{POCH}_{2} \mathrm{CH}_{2}\right), 3.63$ (s, $17 \mathrm{H}, \mathrm{OCH}_{2} \mathrm{CH}_{2} \mathrm{O}$, $\mathrm{H}-3), 3.61-3.57$ (m, 1H, H-4), 3.38 (s, 3H, $\mathrm{OCH}_{3}$ ), 2.82-2.74 (m, 8H, $\left.\mathrm{CH}_{2} \mathrm{CN}\right), 2.46\left(\mathrm{~m}, 4 \mathrm{H}, \mathrm{OCH}_{2} \mathrm{CCH}\right) .{ }^{31} \mathrm{P} \mathrm{NMR}\left(162 \mathrm{MHz}, \mathrm{CDCl}_{3}\right) \delta$ -1.67--3.11 (m, 1P). ${ }^{13} \mathrm{C}$ NMR (100 MHz, CDCl $\left.{ }_{3}\right) \delta 117.1(\mathrm{CN}), 98.3$ (C-1), $79.6\left(\mathrm{OCH}_{2} \mathrm{CCH}\right), 74.9\left(\mathrm{CH}_{2} \mathrm{CCH}, \mathrm{C}-2, \mathrm{C}-5, \mathrm{C}-6\right), 70.2-69.7$ (2m, $\left.\mathrm{POCH}_{2} \mathrm{CH}_{2}, \mathrm{C}-3, \mathrm{C}-4\right), 69.1\left(\mathrm{OCH}_{2} \mathrm{CH}_{2} \mathrm{O}\right), 67.8-62.3$ (5 m, $\mathrm{POCH}_{2}$ ), $58.3\left(\mathrm{OCH}_{2} \mathrm{CCH}\right), 55.7\left(\mathrm{OCH}_{3}\right), 19.5\left(\mathrm{CH}_{2} \mathrm{CN}\right)$. MALDI-TOF $^{+} \mathrm{m} / z$ calcd for $\mathrm{C}_{47} \mathrm{H}_{71} \mathrm{~N}_{4} \mathrm{O}_{26} \mathrm{P}_{4}[\mathrm{M}+\mathrm{H}]^{+}: 1231.96$ found 1231.19. HR-ESI-QToF MS (positive mode): $m / z$ calcd for $\mathrm{C}_{47} \mathrm{H}_{71} \mathrm{~N}_{4} \mathrm{O}_{26} \mathrm{P}_{4}[\mathrm{M}+\mathrm{H}]^{+} 1231.3297$ found 1231.3307.

1-Methyl-2,3,4,6-tetra-O-bis-pentynylphosphotriester- $\alpha$-Dmannopyranoseide 9c. Obtained as a pale yellow oil $(263 \mathrm{mg}$, 98\%). ${ }^{1} \mathrm{H}$ NMR (600 MHz, $\left.\mathrm{CDCl}_{3}\right) \delta 4.89(\mathrm{~d}, J=1.57 \mathrm{~Hz}, 1 \mathrm{H}$, $\mathrm{H}-1)$, 4.78-4.76 (m, 1H, H-2), 4.65-4.62 (m, 1H, H-5), 4.46-4.42 (m, 1H, H-6), 4.24-4.13 (m, 16H, $\left.\mathrm{POCH}_{2} \mathrm{CH}_{2}\right), 3.89-3.86(\mathrm{~m}$, 1H, H-6), 3.38-3.35 (m, 4H, $\left.\mathrm{OCH}_{3}, \mathrm{H}-3\right), 3.32$ (m, 1H, H-4), 2.30 $\left(\mathrm{m}, 16 \mathrm{H}, \mathrm{CH}_{2} \mathrm{CCH}\right), 1.97\left(\mathrm{~m}, 8 \mathrm{H}, \mathrm{CH}_{2} \mathrm{CCH}\right), 1.88(\mathrm{~m}, 16 \mathrm{H}$, $\left.\mathrm{POCH}_{2} \mathrm{CH}_{2}\right) .{ }^{13} \mathrm{C}$ NMR $\left(100 \mathrm{MHz}, \mathrm{CDCl}_{3}\right) \delta 98.5(\mathrm{C}-1), 82.6$ $\left(\mathrm{OCH}_{2} \mathrm{CCH}\right), 69.6-69.4$ (4 s, $\left.\mathrm{CH}_{2} \mathrm{CCH}, \mathrm{C}-2, \mathrm{C}-5, \mathrm{C}-6\right), 64.2,64.1$ (2 s, C-3, C-4), $55.6\left(\mathrm{OCH}_{3}\right), 47.2\left(\mathrm{POCH}_{2}\right), 29.2-29.0(\mathrm{~m}$, $\left.\mathrm{POCH}_{2} \mathrm{CH}_{2}\right), 14.8\left(\mathrm{CH}_{2} \mathrm{CH}_{2} \mathrm{CCH}\right)$. MS MALDI-TOF (positive mode) $\mathrm{m} / \mathrm{z}$ calcd for $\mathrm{C}_{47} \mathrm{H}_{67} \mathrm{O}_{18} \mathrm{P}_{4}[\mathrm{M}+\mathrm{H}]^{+}$: 1043.92 found 1043.80. HR-ESI-QToF MS (positive mode): $\mathrm{m} / \mathrm{z}$ calcd for $\mathrm{C}_{47} \mathrm{H}_{67} \mathrm{O}_{18} \mathrm{P}_{4}[\mathrm{M}+\mathrm{H}]^{+} 1043.3278$ found 1043.3319 .

General procedure for CuAAC conjugation and deacetylation. The alkyne-functionalized compounds (9a-c, 14, 15) 1.0 eq and azido-functionalized fucoside derivative (10) (4 to 9.6 eq) were dissolved in dioxane $(1.4 \mathrm{~mL})$ with triethylammonium acetate buffer $(175 \mu \mathrm{L}, 0.1 \mathrm{M}, \mathrm{pH} 7.7)$ with nanopowder copper $\left(\sim 2 \mathrm{mg}\right.$ ). The resulting mixture was stirred overnight at $70{ }^{\circ} \mathrm{C}$.
The nanopowder copper was eliminated by centrifugation. Then the reaction was diluted in $\mathrm{CH}_{2} \mathrm{Cl}_{2}(15 \mathrm{~mL})$, and washed with brine $(3 \times 15 \mathrm{~mL})$. The organic layer was dried $\left(\mathrm{Na}_{2} \mathrm{SO}_{4}\right)$, filtered and concentrated to dryness. The resulting product was dissolved in acetone $(5 \mathrm{~mL})$ and concentrated ammonia solution (30\%) was added $(20 \mathrm{~mL})$. The mixture was stirred $1 \mathrm{~h}$ at room temperature. After evaporation, the crude product was dissolved in milliQ water, and the solution was passed through a column filled with DOWEX-50W X8 resin, $\mathrm{Na}^{+}$form. After concentration, the residue was purified by $\mathrm{C}_{18}$ flash column chromatography (40 g) (water/ $\mathrm{CH}_{3} \mathrm{CN} /$ triethylammonium acetate buffer $0.1 \mathrm{M} \mathrm{pH} \mathrm{7.7,97/0/3}$ to $47 / 50 / 3$ ) to afford the desired glycoconjugates (1-5).

Glycocluster 1. Obtained as a pale yellow oil (61 mg, 60\%) according to general procedure for CuAAC reactions: 9a (49 $\mathrm{mg}, 0.049 \mathrm{mmol})$ with azido-derivative 10 (105 $\mathrm{mg}, 0.235$ mmol, $4.8 \mathrm{eq}) .{ }^{1} \mathrm{H}$ NMR (400 MHz, $\left.\mathrm{D}_{2} \mathrm{O}\right) \delta 7.96-7.91(\mathrm{~m}, 4 \mathrm{H}$, H-triaz), 4.95 (d, $J=2.8 \mathrm{~Hz}, 1 \mathrm{H}, \mathrm{H}-1 \mathrm{man}), 4.92$ (d, $J=2.8 \mathrm{~Hz}$, $4 \mathrm{H}, \mathrm{H}-1$ fuc), $4.63-4.61$ (m, 8H, $\mathrm{CH}_{2} \mathrm{~N}$-triaz), $4.48-4.40(\mathrm{~m}, 3 \mathrm{H}$, H-2 man, H-3 man, H-5 man), 4.10 (q, $J=4.0 \mathrm{~Hz}, J=8.4 \mathrm{~Hz}, 4 \mathrm{H}$, $\mathrm{H}-5$ fuc), 4.00 (m, 9H, OCH${ }_{2} \mathrm{CH}_{2} \mathrm{~N}-$ triaz, $\left.\mathrm{H}-6 \mathrm{man}\right), 3.91(\mathrm{~m}, 5 \mathrm{H}$, H-6 man, H-3 fuc), 3.85-3.76 (m, 20H, $\mathrm{CH}_{2} \mathrm{O}$-fuc, $\mathrm{POCH}_{2} \mathrm{CH}_{2}$, $\mathrm{H}-2$ fuc), $3.68\left(\mathrm{~m}, 28 \mathrm{H}, \mathrm{OCH}_{2} \mathrm{CH}_{2}, \mathrm{H}-4\right.$ fuc), 3.55 (t, $J=3.6 \mathrm{~Hz}, J$ $=6.4 \mathrm{~Hz}, 1 \mathrm{H}, \mathrm{H}-4 \mathrm{man}), 3.45\left(\mathrm{~s}, 3 \mathrm{H}, \mathrm{OCH}_{3}\right), 2.88-2.78(\mathrm{~m}, 8 \mathrm{H}$, $\mathrm{CH}_{2} \mathrm{CH}_{2} \mathrm{C}$-triaz), 1.98 (s, 8H, $\mathrm{CH}_{2} \mathrm{CH}_{2} \mathrm{C}$-triaz), 1.24 (d, $J=4.4$ $\mathrm{Hz}, 12 \mathrm{H}, \mathrm{H}-6$ fuc). ${ }^{13} \mathrm{C} \mathrm{NMR}\left(100 \mathrm{MHz}, \mathrm{D}_{2} \mathrm{O}\right) 123.9$ (CH-triaz), 98.8 (C-1 fuc, C-1 man), 72.0 (C-4 fuc), 70.9, 70.7 (C-6 man, C-3 fuc), 69.9-69.6 (C-2 fuc, C-4 man, $\mathrm{OCH}_{2} \mathrm{CH}_{2} \mathrm{O}$ ), 69.0 (C-5 fuc), $68.3\left(\mathrm{OCH}_{2} \mathrm{CH}_{2} \mathrm{~N}\right.$-triaz), $67.0\left(\mathrm{POCH}_{2} \mathrm{CH}_{2}\right), 66.8\left(\mathrm{CH}_{2} \mathrm{O}-\right.$ fuc $)$, 65.5, 65.2, 65.0, (C-2 man, C-3 man, C-5 man), $50.3\left(\mathrm{OCH}_{3}\right)$, $50.1\left(\mathrm{CH}_{2} \mathrm{~N}\right.$-triaz), $29.9\left(\mathrm{CH}_{2} \mathrm{CH}_{2} \mathrm{CH}_{2}\right), 29.7\left(\mathrm{CH}_{2} \mathrm{C}\right.$-triaz $), 15.5$ (C-6 fuc). MS MALDI-TOF ${ }^{-} \mathrm{m} / z$ calcd for $\mathrm{C}_{75} \mathrm{H}_{133} \mathrm{~N}_{12} \mathrm{O}_{46} \mathrm{P}_{4}[\mathrm{M}$ $-\mathrm{H}]^{-}: 2062.81$ found 2062.90. HR-ESI-QToF MS (positive mode): $m / z$ calcd for $\mathrm{C}_{75} \mathrm{H}_{137} \mathrm{~N}_{12} \mathrm{O}_{46} \mathrm{P}_{4}[\mathrm{M}+3 \mathrm{H}]^{3+} 688.5900$ found 688.5888 .

Glycocluster 2. Obtained as a pale yellow oil (51 mg, 54\%) according to general procedure for CuAAC reactions: $9 b$ (50 $\mathrm{mg}, 0.041 \mathrm{mmol})$ with azido-derivative $10(73 \mathrm{mg}, 0.164 \mathrm{mmol}$, 4 eq). ${ }^{1} \mathrm{H}$ NMR (400 MHz, $\left.\mathrm{D}_{2} \mathrm{O}\right) \delta 8.21$ (s, 4H, H-triaz), 5.01 (s, $1 \mathrm{H}, \mathrm{H}-1 \mathrm{man}$ ), 4.95 (d, $J=2.8 \mathrm{~Hz}, 4 \mathrm{H}, \mathrm{H}-1$ fuc), 4.71 (t, $J=3.2$ $\mathrm{Hz}, J=6.0 \mathrm{~Hz}, 8 \mathrm{H}, \mathrm{CH}_{2} \mathrm{~N}$-triaz), 4.46-4.35 (m, 3H, H-2 man, H-3 man, H-5 man), 4.17 (d, $J=4.4 \mathrm{~Hz}, 4 \mathrm{H}, \mathrm{H}-5$ fuc), 4.14 (q, $J=4.4$ $\mathrm{Hz}, J=8.8 \mathrm{~Hz}, 8 \mathrm{H}, \mathrm{OCH}_{2} \mathrm{C}$-triaz), 4.06 (t, 9H, $\mathrm{OCH}_{2} \mathrm{CH}_{2} \mathrm{~N}$-triaz, H-6 man), 3.96 (d, $J=2.4 \mathrm{~Hz}, 1 \mathrm{H}, \mathrm{H}-6 \mathrm{man}$ ), 3.94 (dd, 4H, H-3 fuc), 3.87 (m, $8 \mathrm{H}, \mathrm{POCH}_{2} \mathrm{CH}_{2}$ ), 3.84 (d, $J=2.8 \mathrm{~Hz}, 4 \mathrm{H}, \mathrm{H}-2 \mathrm{fuc}$ ), $3.82\left(\mathrm{~m}, 30 \mathrm{H}, \mathrm{CH}_{2} \mathrm{O}-\right.$ fuc, $\left.\mathrm{OCH}_{2} \mathrm{CH}_{2} \mathrm{O}\right), 3.73(\mathrm{~m}, 26 \mathrm{H}$, $\mathrm{OCH}_{2} \mathrm{CH}_{2} \mathrm{O}$ ), 3.68 (d, $J=3.2 \mathrm{~Hz}, 4 \mathrm{H}, \mathrm{H}-4$ fuc), 3.57 (t, $J=3.6$ $\mathrm{Hz}, J=6.4 \mathrm{~Hz}, 1 \mathrm{H}, \mathrm{H}-4 \mathrm{man}$ ), 3.47 (s, 3H, OCH $\left.\mathrm{O}_{3}\right), 1.27$ (d, $J=4.4$ $\mathrm{Hz}, 12 \mathrm{H}, \mathrm{H}-6$ fuc). ${ }^{13} \mathrm{C}$ NMR (100 MHz, $\mathrm{D}_{2} \mathrm{O}$ ) 98.8 (C-1 fuc, C-1 man), 72.0 (C-4 fuc), 69.7 (C-2 fuc, C-3 fuc, C-2 man, C-3 man, C-4 man), 69.4 ( $\mathrm{CH}_{2} \mathrm{O}$-fuc), $69.2\left(\mathrm{OCH}_{2} \mathrm{CH}_{2} \mathrm{~N}\right.$-triaz$), 68.9$ ( $\mathrm{OCH}_{2} \mathrm{C}$-triaz), 68.3 (C-5 man), 67.0 (C-6 man), 66.8 (C-5 fuc), $63.4\left(\mathrm{POCH}_{2} \mathrm{CH}_{2}\right), 55.3(\mathrm{OCH} 3), 50.2\left(\mathrm{CH}_{2} \mathrm{~N}\right.$-triaz), 15.5 (C-6 fuc). MS MALDI-TOF ${ }^{-} \mathrm{m} / \mathrm{z}$ calcd for $\mathrm{C}_{83} \mathrm{H}_{149} \mathrm{~N}_{12} \mathrm{O}_{54} \mathrm{P}_{4}[\mathrm{M}-$ $\mathrm{H}]^{-}: 2303.02$ found 2303.29. HR-ESI-QToF MS (positive mode): $m / z$ calcd for $\mathrm{C}_{83} \mathrm{H}_{153} \mathrm{~N}_{12} \mathrm{O}_{54} \mathrm{P}_{4}[\mathrm{M}+3 \mathrm{H}]^{3+}: 768.6182$ found 768.6204 . 
Glycocluster 3. Obtained as a pale yellow oil (167 mg, 98\%) according to general procedure for CuAAC reactions: 9c (49 $\mathrm{mg}, 0.047 \mathrm{mmol}$ ) with azido-derivative 10 (200 mg, 0.447 mmol, 9.6 eq). ${ }^{1} \mathrm{H}$ NMR (600 MHz, $\left.\mathrm{D}_{2} \mathrm{O}\right) \delta 7.93-7.88(\mathrm{~m}, 8 \mathrm{H}$, H-triaz), 4.98 (d, $J=3.9 \mathrm{~Hz}, 1 \mathrm{H}, \mathrm{H}-1 \mathrm{man}$ ), 4.93 (dd, $J=7.5 \mathrm{~Hz}, J$ $=3.8 \mathrm{~Hz}, 8 \mathrm{H}, \mathrm{H}-1$ fuc), $4.65-4.61$ (m, $16 \mathrm{H}, \mathrm{CH}_{2} \mathrm{~N}$-triaz), $4.29-$ 4.22 (m, 3H, H-2 man, H-3 man, H-5 man), 4.13-4.08 (m, $8 \mathrm{H}$, $\mathrm{H}-5$ fuc), $4.03-3.90\left(\mathrm{~m}, 26 \mathrm{H}, \mathrm{OCH}_{2} \mathrm{CH}_{2} \mathrm{~N}-\right.$ triaz, H-6 man, H-3 fuc), 3.88-3.79 (m, 40H, $\mathrm{CH}_{2} \mathrm{O}$-fuc, $\mathrm{POCH}_{2} \mathrm{CH}_{2}, \mathrm{H}-2$ fuc), 3.763.67 (m, 56H, OCH $\mathrm{CH}_{2} \mathrm{O}, \mathrm{H}-4$ fuc), 3.58 (t, $J=4.91 \mathrm{~Hz}, 1 \mathrm{H}, \mathrm{H}-4$ man), 3.51 (s, $3 \mathrm{H}, \mathrm{OCH}_{3}$ ), 2.87-2.82 (m, $16 \mathrm{H}, \mathrm{CH}_{2} \mathrm{CH}_{2} \mathrm{C}$-triaz), 1.98 (s, 16H, $\mathrm{CH}_{2} \mathrm{CH}_{2} \mathrm{C}$-triaz), 1.25 (t, $J=7.12 \mathrm{~Hz}, 24 \mathrm{H}, \mathrm{H}-6 \mathrm{fuc}$ ). ${ }^{13} \mathrm{C}$ NMR (150 MHz, D $\mathrm{O}$ ) 148.9 (Cq-triaz), 125.0 (CH-triaz), 100.00 (C-1 fuc, C-1 man), 73.2 (C-4 fuc), 71.1, 71.0, 70.9, 70.6, 70.2 (C-2 fuc, C-4 fuc, C-4 man, $\mathrm{OCH}_{2} \mathrm{CH}_{2} \mathrm{O}$, C-6 man, C-3 fuc), 69.5 (C-5 fuc), 68.2-67.9, 66.2 (C-2 man, C-3 man, C-5 man, $\mathrm{CH}_{2} \mathrm{O}$-fuc, $\mathrm{POCH}_{2} \mathrm{CH}_{2}, \mathrm{OCH}_{2} \mathrm{CH}_{2} \mathrm{~N}$-triaz), $51.5\left(\mathrm{OCH}_{3}\right), 51.3$ ( $\mathrm{CH}_{2} \mathrm{~N}$-triaz), $30.9\left(\mathrm{CH}_{2} \mathrm{CH}_{2} \mathrm{CH}_{2}\right), 30.8\left(\mathrm{CH}_{2} \mathrm{C}\right.$-triaz), 16.7 (C-6 fuc). MS MALDI-TOF ${ }^{-} \mathrm{m} / \mathrm{z}$ calcd for $\mathrm{C}_{143} \mathrm{H}_{251} \mathrm{~N}_{24} \mathrm{O}_{74} \mathrm{P}_{4}[\mathrm{M}+$ $\mathrm{H}]^{+}: 3614.54$ found 3614.39 .

Tetraalkynylated branched-phosphodiester-like compound 14. A solution of bis-propargyloxymethyl-2,2-propanol 11 (127 $\mathrm{mg}, 0.65 \mathrm{mmol}, 1 \mathrm{eq})$ in anhydrous acetonitrile $(6.3 \mathrm{~mL})$ was stirred for $1 \mathrm{~h}$ with molecular sieves $(3 \AA)$. Then, bispropargyloxymethyl-2,2-propanol phosphoramidite 13 (309 $\mathrm{mg}, 0.78 \mathrm{mmol}, 1.2 \mathrm{eq})$ and tetrazole $(114 \mathrm{mg}, 1.63 \mathrm{mmol}$, $2.5 \mathrm{eq})$ were added. The mixture was stirred at $30{ }^{\circ} \mathrm{C}$ overnight and the reaction was stopped by addition of water. $\mathrm{A}_{26}\left(\mathrm{IO}_{4}{ }^{-}\right)$ resin $(2.5 \mathrm{~g}, 6.25 \mathrm{mmol}, 9.6 \mathrm{eq})$ was added and the mixture was stirred overnight. After filtration of the resin and addition of dichloromethane $(100 \mathrm{~mL})$, the reaction was washed with an aqueous saturated solution of $\mathrm{NaHCO}_{3}(150 \mathrm{~mL})$ and brine $(150 \mathrm{~mL})$. The organic layer was dried $\left(\mathrm{Na}_{2} \mathrm{SO}_{4}\right)$, filtered and concentrated to afford the desired tetra-alkynylated derivative 14 (85 mg, 26\%). ${ }^{1} \mathrm{H}$ NMR (400 MHz, $\mathrm{CDCl}_{3}$ ) $\delta 4.26$ (dt, $J=8.45$ $\left.\mathrm{Hz}, J=6.42 \mathrm{~Hz}, 2 \mathrm{H}, \mathrm{POCH}_{2} \mathrm{CH}_{2}\right), 4.14(\mathrm{dd}, 8 \mathrm{H}, J=2.36 \mathrm{~Hz}, J=$ $1.78 \mathrm{~Hz}, \mathrm{OCH}_{2} \mathrm{CCH}$ ), $3.56\left(\mathrm{~s}, 4 \mathrm{H}, \mathrm{POCH}_{2} \mathrm{C}_{\mathrm{q}}\right), 3.50$ (d, $J=2.60$ $\left.\mathrm{Hz}, 8 \mathrm{H}, \mathrm{OCH}_{2} \mathrm{C}_{\mathrm{q}}\right), 2.78\left(\mathrm{td}, J=6.41 \mathrm{~Hz}, J=0.59 \mathrm{~Hz}, 2 \mathrm{H}, \mathrm{CH}_{2} \mathrm{CN}\right)$, $2.43\left(\mathrm{t}, J=2.37 \mathrm{~Hz}, 4 \mathrm{H}, \mathrm{OCH}_{2} \mathrm{CCH}\right), 0.90\left(\mathrm{~s}, 6 \mathrm{H}, \mathrm{CH}_{3}\right) .{ }^{13} \mathrm{C} \mathrm{NMR}$ $(100 \mathrm{MHz}, \mathrm{CDCl} 3) \delta 113.1(\mathrm{CN}), 79.7\left(\mathrm{OCH}_{2} \mathrm{CCH}\right), 74.5$

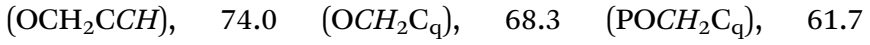
$\left(\mathrm{POCH}_{2} \mathrm{CH}_{2}\right), 58.7\left(\mathrm{OCH}_{2} \mathrm{CCH}\right), 40.5\left(\mathrm{C}_{\mathrm{q}}\right.$-tris $), 19.6\left(\mathrm{CH}_{2} \mathrm{CN}\right)$, $17.4\left(\mathrm{CH}_{3}\right)$. MS MALDI-TOF ${ }^{-} \mathrm{m} / z$ calcd for $\mathrm{C}_{25} \mathrm{H}_{35} \mathrm{NO}_{8} \mathrm{P}[\mathrm{M}+$ $\mathrm{H}]^{+}: 508.52$ found 508.25. HR-ESI-QToF MS (positive mode): $\mathrm{m} /$ $z$ calcd for $\mathrm{C}_{25} \mathrm{H}_{35} \mathrm{NO}_{8} \mathrm{P}[\mathrm{M}+\mathrm{H}]^{+} 508.2100$ found 508.2078.

Hexaalkynylated branched-phosphodiester-like compound 15. A solution of bis-propargyloxymethyl-2,2-propane-1,3-diol 12 (54 mg, $0.25 \mathrm{mmol}, 1 \mathrm{eq})$ in anhydrous acetonitrile $(2.0 \mathrm{~mL})$ and a solution of tetrazole $\left(0.4 \mathrm{M}\right.$ in anhydrous $\mathrm{CH}_{3} \mathrm{CN}, 3.1$ $\mathrm{mL}, 1.25 \mathrm{mmol}, 5 \mathrm{eq})$ was stirred for $1.5 \mathrm{~h}$ with molecular sieves (3 ̊). Then, bis-propargyloxymethyl-2,2-propanol phosphoramidite 13 (252 mg, $0.64 \mathrm{mmol}, 2.5 \mathrm{eq}$ ) were added. The mixture was stirred at $30{ }^{\circ} \mathrm{C}$ for $4 \mathrm{~h}$ and the reaction was stopped by addition of water. $\mathrm{A}_{26}\left(\mathrm{IO}_{4}{ }^{-}\right)$resin $(500 \mathrm{mg}, 1.25$ mmol, $5 \mathrm{eq}$ ) was added and the mixture was stirred for $1 \mathrm{~h}$. After filtration of the resin and addition of dichloromethane $(30 \mathrm{~mL})$, the reaction was washed with an aqueous saturated solution of $\mathrm{NaHCO}_{3}(30 \mathrm{~mL})$ and brine $(30 \mathrm{~mL})$. The organic layer was dried $\left(\mathrm{Na}_{2} \mathrm{SO}_{4}\right)$, filtered and concentrated to afford the desired hexa-alkynylated derivative $15(203 \mathrm{mg}, 97 \%) .{ }^{1} \mathrm{H}$ NMR (400 MHz, $\mathrm{CDCl}_{3}$ ) $\delta$ 4.29-4.25 (m, 4H, $\mathrm{POCH}_{2} \mathrm{CH}_{2}$ ), 4.13$4.09\left(\mathrm{~m}, 16 \mathrm{H}, \mathrm{OCH}_{2} \mathrm{CCH}, \mathrm{POCH}_{2} \mathrm{C}_{\mathrm{q}}\right), 3.98(\mathrm{~d}, J=4.28 \mathrm{~Hz}, 4 \mathrm{H}$, $\left.\mathrm{OCH}_{2} \mathrm{C}_{\mathrm{q}}\right), 3.54\left(\mathrm{~s}, 4 \mathrm{H}, \mathrm{POCH}_{2} \mathrm{C}_{\mathrm{q}}\right), 3.40-3.36\left(\mathrm{~m}, 8 \mathrm{H}, \mathrm{OCH}_{2} \mathrm{C}_{\mathrm{q}}\right)$, 2.79-2.76 (m, $\left.4 \mathrm{H}, \mathrm{CH}_{2} \mathrm{CN}\right), 2.47-2.45\left(\mathrm{~m}, 6 \mathrm{H}, \mathrm{OCH}_{2} \mathrm{CCH}\right), 0.99$ $\left(\mathrm{s}, 6 \mathrm{H}, \mathrm{CH}_{3}\right) \cdot{ }^{13} \mathrm{C} \mathrm{NMR}(100 \mathrm{MHz}, \mathrm{CDCl} 3) \delta 116.6(\mathrm{CN}), 79.9$ $\left(\mathrm{OCH}_{2} \mathrm{CCH}\right), 75.2\left(\mathrm{OCH}_{2} \mathrm{CCH}\right), 74.8\left(\mathrm{OCH}_{2} \mathrm{C}_{\mathrm{q}}\right), 67.3,66.2$ $\left(\mathrm{POCH}_{2} \mathrm{C}_{\mathrm{q}}\right), 62.1\left(\mathrm{POCH}_{2} \mathrm{CH}_{2}\right), 58.8\left(\mathrm{OCH}_{2} \mathrm{CCH}\right), 40.6\left(\mathrm{C}_{\mathrm{q}}\right.$-tris $)$, $37.1(\mathrm{Cq}), 19.8\left(\mathrm{CH}_{2} \mathrm{CN}\right), 17.0\left(\mathrm{CH}_{3}\right) . \mathrm{MS}_{\mathrm{MALDI}} \mathrm{TOF}{ }^{-} \mathrm{m} / \mathrm{z}$ calcd for $\mathrm{C}_{39} \mathrm{H}_{53} \mathrm{~N}_{2} \mathrm{O}_{14} \mathrm{P}_{2}[\mathrm{M}+\mathrm{H}]^{+}$: 835.79 found 835.33. HRESI-QToF MS (positive mode): $\mathrm{m} / z$ calcd for $\mathrm{C}_{39} \mathrm{H}_{53} \mathrm{~N}_{2} \mathrm{O}_{14} \mathrm{P}_{2}[\mathrm{M}$ $+\mathrm{H}]^{+}$835.2972 found 835.2978.

Glycocluster 4. Obtained as a pale yellow oil (113 mg, 99\%) according to general procedure for CuAAC reaction: 14 (33 mg, $0.065 \mathrm{mmol})$ with azido-derivative $10(139 \mathrm{mg}, 0.312 \mathrm{mmol}, 4.8$ eq). ${ }^{1} \mathrm{H}$ NMR $\left(600 \mathrm{MHz}, \mathrm{D}_{2} \mathrm{O}\right) \delta 8.06(\mathrm{~s}, 4 \mathrm{H}, \mathrm{H}$-triaz), $4.89(\mathrm{~d}, J=$ $3.9 \mathrm{~Hz}, 4 \mathrm{H}, \mathrm{H}-1$ fuc), 4.64 (t, $J=5.0 \mathrm{~Hz}, 8 \mathrm{H}, \mathrm{CH}_{2} \mathrm{~N}$-triaz), 4.62 (s, $8 \mathrm{H}, \mathrm{OCH}_{2}$-triaz), 4.07 (q, $J=6.6 \mathrm{~Hz}, 4 \mathrm{H}, \mathrm{H}-5$ fuc), 3.99 (t, $J=5.0$ $\mathrm{Hz}, 8 \mathrm{H}, \mathrm{OCH}_{2} \mathrm{CH}_{2} \mathrm{~N}$-triaz), 3.87 (dd, $J=10.4 \mathrm{~Hz}, J=3.4 \mathrm{~Hz}, 4 \mathrm{H}$, $\mathrm{H}-3$ fuc), 3.82-3.77 (m, $12 \mathrm{H}, \mathrm{CH}_{2} \mathrm{O}$-fuc, $\mathrm{H}-2$ fuc), $3.75(\mathrm{~s}, 4 \mathrm{H}$, $\mathrm{POCH}_{2} \mathrm{C}_{\mathrm{q}}$ ), 3.67-3.64 (m, 28H, OCH $\mathrm{CH}_{2} \mathrm{O}, \mathrm{H}-4$ fuc), 3.41 (d, $J=$ $3.4 \mathrm{~Hz}, 8 \mathrm{H}, \mathrm{OCH}_{2}-\mathrm{C}_{\mathrm{q}}$ ), 1.21 (d, $\left.J=6.6 \mathrm{~Hz}, 12 \mathrm{H}, \mathrm{H}-6 \mathrm{fuc}\right), 0.86$ (s, $\left.6 \mathrm{H}, \mathrm{CH}_{3}\right) .{ }^{31} \mathrm{P}$ NMR $\left(243 \mathrm{MHz}, \mathrm{D}_{2} \mathrm{O}\right) \delta 0.66(\mathrm{~s}, 1 \mathrm{P}) .{ }^{13} \mathrm{C} \mathrm{NMR}$ (150 MHz, $\left.\mathrm{D}_{2} \mathrm{O}\right) \delta 144.4\left(\mathrm{C}_{\mathrm{q}}\right.$-triaz), 125.5 (CH-triaz), $98.8(\mathrm{C}-1)$, $72.6\left(\mathrm{OCH}_{2} \mathrm{C}_{\mathrm{q}}\right), 69.9-69.7$ (4s, C-2, C-3, C-4, $\left.\mathrm{OCH}_{2} \mathrm{CH}_{2} \mathrm{O}\right), 69.0$ (C-5), $68.3\left(\mathrm{OCH}_{2} \mathrm{CH}_{2} \mathrm{~N}\right.$-triaz), $67.0\left(\mathrm{POCH}_{2} \mathrm{C}_{\mathrm{q}}\right), 66.8\left(\mathrm{CH}_{2} \mathrm{O}-\right.$ fuc $)$, $63.8\left(\mathrm{OCH}_{2}\right.$-triaz), $50.2\left(\mathrm{CH}_{2} \mathrm{~N}\right.$-triaz), $40.6\left(\mathrm{C}_{\mathrm{q}}\right.$-tris $), 16.5(\mathrm{CH} 3)$, 15.5 (C-6). MS MALDI-TOF ${ }^{-} m / z$ calcd for $\mathrm{C}_{70} \mathrm{H}_{122} \mathrm{~N}_{12} \mathrm{O}_{36} \mathrm{P}[\mathrm{M}$ $-\mathrm{H}]^{-}: 1738.75$ found 1738.09. HR-ESI-QToF MS (positive mode): $m / z$ calcd for $\mathrm{C}_{70} \mathrm{H}_{125} \mathrm{~N}_{12} \mathrm{O}_{36} \mathrm{P}[\mathrm{M}+2 \mathrm{H}]^{++} 870.4029$ found 870.4041 .

Glycocluster 5. Obtained as a pale yellow oil (120 mg, 98\%) according to general procedure for CuAAC reactions: 15 (36 $\mathrm{mg}, 0.043 \mathrm{mmol})$ with azido-derivative 10 (127 mg, 0.284 mmol, 6.6 eq). ${ }^{1} \mathrm{H}$ NMR (300 MHz, $\left.\mathrm{D}_{2} \mathrm{O}\right) d 8.04$ (s, 6H, H-triaz), 4.87 (d, $J=3.6 \mathrm{~Hz}, 6 \mathrm{H}, \mathrm{H}-1$ fuc), $4.60-4.56$ (m, $24 \mathrm{H}, \mathrm{CH}_{2} \mathrm{~N}-$ triaz, $\mathrm{OCH}_{2}$-triaz), 4.04 (q, $J=6.9 \mathrm{~Hz}, 6 \mathrm{H}, \mathrm{H}-5$ fuc), $3.94(\mathrm{~m}, 12 \mathrm{H}$, $\mathrm{OCH}_{2} \mathrm{CH}_{2} \mathrm{~N}$-triaz), 3.86 (dd, $J=8.4 \mathrm{~Hz}, J=3.3 \mathrm{~Hz}, 6 \mathrm{H}, \mathrm{H}-3 \mathrm{fuc}$ ), 3.81-3.71 (m, 26H, $\mathrm{CH}_{2} \mathrm{O}-$ fuc, $\mathrm{H}-2$ fuc, $\left.\mathrm{POCH}_{2} \mathrm{C}_{\mathrm{q}}\right), 3.63(\mathrm{~m}$, $42 \mathrm{H}, \mathrm{OCH}_{2} \mathrm{CH}_{2} \mathrm{O}, \mathrm{H}-4$ fuc), 3.52-3.49 (m, $\left.12 \mathrm{H}, \mathrm{OCH}_{2}-\mathrm{C}_{\mathrm{q}}\right), 1.20$ (dd, $J=10.2 \mathrm{~Hz}, J=6.6 \mathrm{~Hz}, 18 \mathrm{H}, \mathrm{H}-6$ fuc), $0.84\left(\mathrm{~s}, 6 \mathrm{H}, \mathrm{CH}_{3}\right) .{ }^{31} \mathrm{P}$ NMR (243 MHz, D2O) $\delta 0.48(\mathrm{~s}, 1 \mathrm{P}) .{ }^{13} \mathrm{C} \mathrm{NMR}\left(150 \mathrm{MHz}, \mathrm{D}_{2} \mathrm{O}\right) \delta$ $145.7\left(\mathrm{C}_{\mathrm{q}}\right.$-triaz), 126.5 (CH-triaz), $99.9(\mathrm{C}-1), 73.1\left(\mathrm{OCH}_{2}-\mathrm{C}_{\mathrm{q}}\right)$, 71.1-70.8 (4 s, C-2, C-3, C-4, $\mathrm{OCH}_{2} \mathrm{CH}_{2} \mathrm{O}$ ), 69.4 (C-5), 68.2 $\left(\mathrm{OCH}_{2} \mathrm{CH}_{2} \mathrm{~N}\right.$-triaz), $67.9\left(2 \mathrm{~s}, \mathrm{POCH}_{2} \mathrm{C}_{\mathrm{q}}, \mathrm{CH}_{2} \mathrm{O}-\right.$ fuc $), 65.1\left(\mathrm{OCH}_{2}-\right.$ triaz), 51.4 ( $\mathrm{CH}_{2} \mathrm{~N}$-triaz), 48.0 ( $\mathrm{C}_{\mathrm{q}}$-tris), 16.7 (CH3), 16.6 (C-6). MS MALDI-TOF ${ }^{-} \mathrm{m} / \mathrm{z}$ calcd for $\mathrm{C}_{105} \mathrm{H}_{183} \mathrm{~N}_{18} \mathrm{O}_{56} \mathrm{P}_{2}[\mathrm{M}-\mathrm{H}]^{-}$: 2655.61 found 2655.67. HR-ESI-QToF MS (positive mode): $\mathrm{m} / \mathrm{z}$ calcd for $\mathrm{C}_{105} \mathrm{H}_{187} \mathrm{~N}_{18} \mathrm{O}_{56} \mathrm{P}_{2}[\mathrm{M}+3 \mathrm{H}]^{3+} 886.0605$ found 886.0662 .

\section{Binding studies}

Hemagglutination inhibition assays (HIA). Hemagglutination inhibition assays (HIA) were performed in U-shaped 96-well microtitre plates. Rabbit erythrocytes were purchased from Biomérieux and used without further washing. Erythrocytes were diluted to a $8 \%$ solution in $\mathrm{NaCl}(100 \mathrm{mM})$. BambL solutions of $3 \mu \mathrm{M}$ were prepared in TRIS-HCl $20 \mathrm{mM}$ (TRIS = 
tris(hydroxymethyl)aminomethane), $\mathrm{NaCl} 100 \mathrm{mM}$, and $\mathrm{CaCl}_{2}$ $100 \mathrm{mM}$. The hemagglutination unit (HU) was first obtained by addition of the $4 \%$ erythrocyte solution $(50 \mu \mathrm{L})$ to aliquots $(50 \mu \mathrm{L})$ of sequential (twice) lectin dilutions. The mixture was incubated at $25{ }^{\circ} \mathrm{C}$ for $30 \mathrm{~min}$. The HU was measured as the minimum lectin concentration required to observe hemagglutination. For the following lectin-inhibition assays, lectin concentrations of $4 \mathrm{HU}$ were used. For BambL, this concentration was found to be $3 \mu \mathrm{M}$. Subsequent inhibition assays were then carried out by the addition of lectin solution $(25 \mu \mathrm{L}$, at the required concentration) to sequential dilutions $(50 \mu \mathrm{L})$ of glycoclusters, monomer molecules, and controls. These solutions were incubated at $37{ }^{\circ} \mathrm{C}$ for $30 \mathrm{~min}$, then $8 \%$ erythrocyte solution $(25 \mu \mathrm{L})$ was added, followed by an additional incubation at $37{ }^{\circ} \mathrm{C}$ for $1 \mathrm{~h}$. The minimum inhibitory concentration for each molecule was determined for each duplicate

Surface plasmon resonance. SPR inhibition experiments were performed on a Biacore X100 instrument (GE Healthcare) at $25{ }^{\circ} \mathrm{C}$ in HBS buffer $(10 \mathrm{mM}$ Hepes/ $\mathrm{NaOH}, \mathrm{pH} 7.5,150 \mathrm{mM}$ $\mathrm{NaCl}, 0.05 \%$ Tween 20 ) at a flow rate of $10 \mu \mathrm{l} \mathrm{min}^{-1}$. Streptavidin was immobilized on a research grade CM5 chip using standard procedures, and 200 resonance units of biotinylated polyacrylamide- $\alpha$-L-fucoside probe (Lectinity, 200 $\mu \mathrm{g} \mathrm{mL^{-1 }}$ ) were captured on channels 2 . Inhibition experiments were performed with the fucosylated channel 2 , and plots represent the subtracted data (channel 2-channel 1). Inhibition studies consisted of the injection (association 180 $\mathrm{s}$, dissociation $180 \mathrm{~s})$ of incubated $(30 \mathrm{~min}$ at room temperature) mixtures of BambL $(0.2 \mu \mathrm{M})$ and various concentrations of inhibitor (3-fold cascade dilutions). For each inhibition assay, BambL was injected to observe the full adhesion of the lectin onto the sugar-coated surface $(0 \%$ inhibition). The chip was fully regenerated by two successive injections of L-fucose (120 s, $1 \mathrm{M}$ in running buffer). Binding was measured as resonance units over time after blank subtraction, and data were then evaluated by using the Biacore X100 evaluation software, version 2.0. For $\mathrm{IC}_{50}$ determination, the response was considered as the amount of lectin bound to the sugar surface at the end of injection. Inhibition curves were obtained by plotting the percentage of inhibition against the inhibitor concentration (logarithmic scale).

Microcalorimetry. Recombinant lyophilized BambL was dissolved in buffer (20 mM TRIS-HCl, pH 7.5, NaCl $150 \mathrm{mM}$ ) and degassed. The protein concentration was checked by measuring $A_{280}$ by using a theoretical molar extinction coefficient of 40,450 $\mathrm{M}^{-1} \mathrm{~cm}^{-1}$. Carbohydrate ligands were dissolved in the same buffer, degassed, and loaded in the injection syringe. ITC was performed with a VP-ITC microcalorimeter (Microcal, GE Healthcare). The BambL solution was placed in a $1.4478 \mathrm{~mL}$ sample cell at $25{ }^{\circ} \mathrm{C}$. Titration was performed with $10 \mu \mathrm{L}$ injections of carbohydrate ligands every 300 s. Data were fitted with MicroCal Origin 7 software according to standard procedures. The fitted data yielded the stoichiometry $(n)$, association constant $\left(K_{a}\right)$, and enthalpy of binding $(\Delta H)$. Other thermodynamic parameters (i.e. changes in free energy $(\Delta G)$ and entropy $(\Delta S)$ ) were calculated from the equation $\Delta G=\Delta H-T \Delta S=-R T \ln K_{a}$, in which $T$ is the absolute temperature and $R=8.314 \mathrm{~J} \mathrm{~mol}^{-1} \mathrm{~K}^{-1}$. Two independent titrations were performed for each ligand tested.

\section{Acknowledgements}

This work was financially supported by ANR-12-BSV5-0020. C.L. thanks the Universite Montpellier 2 for the award of a research studentship. N.G. was awarded a $\mathrm{PhD}$ studentship from Région Rhône-Alpes Cluster Chimie. A.A. is supported by ANR-11-BSV5-002. The COST actions CM1102 and BM1003 and the Labex ARCANE (ANR-11-LABX-003) are thanked for financial support. F.M. is member of Inserm.

\section{References}

1 C. R. Bertozzi and L. L. Kiessling, Science, 2001, 291, 2357-2364.

2 H. Lis and N. Sharon, Chem. Rev., 1998, 98, 637-674.

3 A. Varki, Glycobiology, 1993, 3, 97-130.

4 Y. M. Chabre and R. Roy, Adv. Carbohydr. Chem. Biochem., 2010, 63, 165-393.

5 N. Spinelli, E. Defrancq and F. Morvan, Chem. Soc. Rev., 2013, 42, 4557-4573.

6 J. L. Reymond, M. Bergmann and T. Darbre, Chem. Soc. Rev., 2013, 42, 4814-4822.

7 Y. C. Lee and R. T. Lee, Acc. Chem. Res., 1995, 28, 321-327.

8 J. J. Lundquist and E. J. Toone, Chem. Rev., 2002, 102, 555-578.

9 A. Imberty, Y. M. Chabre and R. Roy, Chem.-Eur. J., 2008, 14, 7490-7499.

10 N. Sharon, Adv. Exp. Med. Biol., 1996, 408, 1-8.

11 A. Bernardi, J. Jiménez-Barbero, A. Casnati, C. De Castro, T. Darbre, F. Fieschi, J. Finne, H. Funken, K. E. Jaeger, M. Lahmann, T. K. Lindhorst, M. Marradi, P. Messner, A. Molinaro, P. V. Murphy, C. Nativi, S. Oscarson, S. Penadés, F. Peri, R. J. Pieters, O. Renaudet, J. L. Reymond, B. Richichi, J. Rojo, F. Sansone, C. Schäffer, W. B. Turnbull, T. Velasco-Torrijos, S. Vidal, S. Vincent, T. Wennekes, H. Zuilhof and A. Imberty, Chem. Soc. Rev., 2013, 42, 4709-4727.

12 Z. H. Soomro, S. Cecioni, H. Blanchard, J. P. Praly, A. Imberty, S. Vidal and S. E. Matthews, Org. Biomol. Chem., 2011, 9, 6587-6597.

13 S. Cecioni, S. Faure, U. Darbost, I. Bonnamour, H. ParrotLopez, O. Roy, C. Taillefumier, M. Wimmerova, J. P. Praly, A. Imberty and S. Vidal, Chem.-Eur. J., 2011, 17, 2146-2159.

14 S. Cecioni, J. P. Praly, S. E. Matthews, M. Wimmerova, A. Imberty and S. Vidal, Chem.-Eur. J., 2012, 18, 6250-6263.

15 S. Cecioni, S. E. Matthews, H. Blanchard, J. P. Praly, A. Imberty and S. Vidal, Carbohydr. Res., 2012, 356, 132-141.

16 G. Timpano, G. Tabarani, M. Anderluh, D. Invernizzi, F. Vasile, D. Potenza, P. M. Nieto, J. Rojo, F. Fieschi and A. Bernardi, ChemBioChem, 2008, 9, 1921-1930.

17 M. Andreini, D. Doknic, I. Sutkeviciute, J. J. Reina, J. X. Duan, E. Chabrol, M. Thepaut, E. Moroni, F. Doro, L. Belvisi, J. Weiser, J. Rojo, F. Fieschi and A. Bernardi, Org. Biomol. Chem., 2011, 9, 5778-5786. 
18 S. Sattin, A. Daghetti, M. Thepaut, A. Berzi, M. SanchezNavarro, G. Tabarani, J. Rojo, F. Fieschi, M. Clerici and A. Bernardi, ACS Chem. Biol., 2010, 5, 301-312.

19 A. Berzi, J. J. Reina, R. Ottria, I. Sutkeviciute, P. Antonazzo, M. Sanchez-Navarro, E. Chabrol, M. Biasin, D. Trabattoni, I. Cetin, J. Rojo, F. Fieschi, A. Bernardi and M. Clerici, AIDS, 2012, 26, 127-137.

20 C. K. Cusumano, J. S. Pinkner, Z. F. Han, S. E. Greene, B. A. Ford, J. R. Crowley, J. P. Henderson, J. W. Janetka and S. J. Hultgren, Sci. Transl. Med., 2011, 3, 109ra115.

21 Z. F. Han, J. S. Pinkner, B. Ford, E. Chorell, J. M. Crowley, C. K. Cusumano, S. Campbell, J. P. Henderson, S. J. Hultgren and J. W. Janetka, J. Med. Chem., 2012, 55, 3945-3959.

22 M. Scharenberg, O. Schwardt, S. Rabbani and B. Ernst, J. Med. Chem., 2012, 55, 9810-9816.

23 S. G. Gouin, A. Wellens, J. Bouckaert and J. Kovensky, ChemMedChem, 2009, 4, 749-755.

24 A. J. Cagnoni, O. Varela, S. G. Gouin, J. Kovensky and M. L. Uhrig, J. Org. Chem., 2011, 76, 3064-3077.

25 T. Coenye, E. Mahenthiralingam, D. Henry, J. J. LiPuma, S. Laevens, M. Gillis, D. P. Speert and P. Vandamme, Int. J. Syst. Evol. Microbiol., 2001, 51, 1481-1490.

26 L. Pirone, L. Chiarini, C. Dalmastri, A. Bevivino and S. Tabacchioni, Environ. Microbiol., 2005, 7, 1734-1742.

27 J. L. Parke and D. Gurian-Sherman, Annu. Rev. Phytopathol., 2001, 39, 225-258.

28 P. Vandamme and P. Dawyndt, Syst. Appl. Microbiol., 2011, 34, 87-95.

29 L. Chiarini, A. Bevivino, C. Dalmastri, S. Tabacchioni and P. Visca, Trends Microbiol., 2006, 14, 277-286.

30 L. Saiman and J. Siegel, Clin. Microbiol. Rev., 2004, 17, 57-71.

31 S. D. Aaron, W. Ferris, D. A. Henry, D. P. Speert and N. E. Macdonald, Am. J. Respir. Crit. Care Med., 2000, 161, 1206-1212.

32 A. Imberty and A. Varrot, Curr. Opin. Struct. Biol., 2008, 18, 567-576.

33 K. A. Karlsson, Adv. Exp. Med. Biol., 2001, 491, 431-443.

34 M. C. Glick, V. A. Kothari, A. Liu, L. I. Stoykova and T. F. Scanlin, Biochimie, 2001, 83, 743-747.

35 E. Mitchell, C. Houles, D. Sudakevitz, M. Wimmerova, C. Gautier, S. Perez, A. M. Wu, N. Gilboa-Garber and A. Imberty, Nat. Struct. Biol., 2002, 9, 918-921.
36 O. Šulák, G. Cioci, M. Delia, M. Lahmann, A. Varrot, A. Imberty and M. Wimmerová, Structure, 2010, 18, 59-72. 37 O. Šulák, G. Cioci, E. Lameignère, V. Balloy, A. Round, I. Gutsche, L. Malinovská, M. Chignard, P. Kosma, F. Aubert, C. L. Marolda, M. A. Valvano, M. Wimmerová and A. Imberty, PLoS Pathog., 2011, 7, e1002238.

38 A. Audfray, J. Claudinon, S. Abounit, N. Ruvoen-Clouet, G. Larson, D. F. Smith, M. Wimmerova, J. Le Pendu, W. Romer, A. Varrot and A. Imberty, J. Biol. Chem., 2012, 287, 4335-4347.

39 M. Wimmerova, E. Mitchell, J. F. Sanchez, C. Gautier and A. Imberty, J. Biol. Chem., 2003, 278, 27059-27067.

40 N. Kostlanová, E. P. Mitchell, H. Lortat-Jacob, S. Oscarson, M. Lahmann, N. Gilboa-Garber, G. Chambat, M. Wimmerová and A. Imberty, J. Biol. Chem., 2005, 280, 27839-27849.

41 S. L. Beaucage and M. H. Caruthers, Tetrahedron Lett., 1981, 22, 1859-1862.

42 V. V. Rostovtsev, L. G. Green, V. V. Fokin and K. B. Sharpless, Angew. Chem., Int. Ed., 2002, 41, 2596-2599.

43 C. W. Tornoe, C. Christensen and M. Meldal, J. Org. Chem., 2002, 67, 3057-3064.

44 M. Dubber and T. K. Lindhorst, J. Org. Chem., 2000, 65, 5275-5281.

45 J. E. Cadotte, F. Smith and D. Spriestersbach, J. Am. Chem. Soc., 1952, 74, 1501-1504.

46 G. Pourceau, A. Meyer, J. J. Vasseur and F. Morvan, J. Org. Chem., 2009, 74, 6837-6842.

47 B. Gerland, A. Goudot, G. Pourceau, A. Meyer, V. Dugas, S. Cecioni, S. Vidal, E. Souteyrand, J. J. Vasseur, Y. Chevolot and F. Morvan, Bioconjugate Chem., 2012, 23, 1534-1547.

48 C. Ligeour, A. Meyer, J. J. Vasseur and F. Morvan, Eur. J. Org. Chem., 2012, 1851-1856.

49 C. Dueymes, A. Schonberger, I. Adamo, A. E. Navarro, A. Meyer, M. Lange, J. L. Imbach, F. Link, F. Morvan and J. J. Vasseur, Org. Lett., 2005, 7, 3485-3488.

50 F. Morvan, A. Meyer, A. Jochum, C. Sabin, Y. Chevolot, A. Imberty, J. P. Praly, J. J. Vasseur, E. Souteyrand and S. Vidal, Bioconjugate Chem., 2007, 18, 1637-1643.

51 M. Ortega-Munoz, F. Perez-Balderas, J. Morales-Sanfrutos, F. Hernandez-Mateo, J. Isac-Garcia and F. SantoyoGonzalez, Eur. J. Org. Chem., 2009, 2454-2473. 